\title{
Biogeochemical response of alpine lakes to a recent increase in dust deposition in the Southwestern, US
}

\author{
A. P. Ballantyne ${ }^{1}$, J. Brahney ${ }^{1}$, D. Fernandez ${ }^{1}$, C. L. Lawrence ${ }^{2}$, J. Saros ${ }^{3}$, and J. C. Neff ${ }^{1}$ \\ ${ }^{1}$ Department of Geological Sciences, University of Colorado, Boulder, Colorado, USA \\ ${ }^{2}$ United States Geologial Survey, Menlo Park, California, USA \\ ${ }^{3}$ Climate Change Institute and School of Biology, University of Maine, Orono, Maine, USA
}

Received: 7 October 2010 - Published in Biogeosciences Discuss.: 1 December 2010

Revised: 13 August 2011 - Accepted: 18 August 2011 - Published: 23 September 2011

\begin{abstract}
The deposition of dust has recently increased significantly over some regions of the western US. Here we explore how changes in dust deposition have affected the biogeochemistry of two alpine watersheds in Colorado, US. We first reconstruct recent changes in the mass accumulation rate of sediments and then we use isotopic measurements in conjunction with a Bayesian mixing model to infer that approximately $95 \%$ of the inorganic fraction of lake sediments is derived from dust. Elemental analyses of modern dust indicate that dust is enriched in $\mathrm{Ca}, \mathrm{Cr}, \mathrm{Cu}, \mathrm{Mg}, \mathrm{Ni}$, and in one watershed, $\mathrm{Fe}$ and $\mathrm{P}$ relative to bedrock. The increase in dust deposition combined with its enrichment in certain elements has altered the biogeochemisty of these systems. Both lakes showed an increase in primary productivity as evidenced by a decrease in carbon isotopic discrimination; however, the cause of increased primary productivity varies due to differences in watershed characteristic. The lake in the larger watershed experienced greater atmospheric $\mathrm{N}$ loading and less $\mathrm{P}$ loading from the bedrock leading to a greater N:P flux ratio. In contrast, the lake in the smaller watershed experienced less atmospheric $\mathrm{N}$ loading and greater $\mathrm{P}$ loading from the bedrock, leading to a reduced N:P flux ratio. As a result, primary productivity was more constrained by $\mathrm{N}$ availability in the smaller watershed. N-limited primary productivity in the smaller watershed was partly ameliorated by an increase in nitrogen fixation as indicated by reduced nitrogen isotopic values in more contemporary sediments. This study illustrates that alpine watersheds are excellent integrators of changes in atmospheric deposition, but that the biogeochemical response of these watersheds may be mediated by their physical (i.e. watershed area) and chemical (i.e. underlying geology) properties.
\end{abstract}

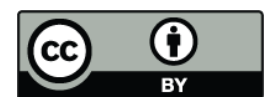

Correspondence to: A. P. Ballantyne (ashley.ballantyne@colorado.edu)

\section{Introduction}

Nutrients are often transported between ecosystems, leading to the depletion of nutrients from source ecosystems and the enrichment of nutrients in sink ecosystems (Polis et al., 1997). Atmospheric aerosols can be an important vector of nutrients from source ecosystems to sink ecosystems. This is especially true for arid regions where dust emissions can result in substantial nutrient subsidies to sink ecosystems in the form of $\mathrm{Fe}, \mathrm{P}$, and $\mathrm{N}$ deposition (Duce and Tindale, 1991; Okin et al., 2004). Recent evidence of increased dust emissions due to extensive grazing and prolonged aridity in the Western US suggests an increase in nutrient loading to nearby alpine watersheds (Neff et al., 2008; Munson et al., 2011). At the same time rapid urbanization of the Western US has lead to a massive and sudden increase in the amount of dry and wet deposition of N (Fenn et al., 2003). Thus changes in the intensity and patterns of human land-use have greatly altered the biogeochemical cycles of $\mathrm{N}$ and $\mathrm{P}$ in the Western US, with potential impacts for both source and sink ecosystems.

A large amount of research has focused on the ecosystem impacts of increased $\mathrm{N}$ deposition as a result of fossil fuel emissions (Likens et al., 1996; Vitousek et al., 1997). It has been estimated that total $\mathrm{N}$ deposition in the form of $\mathrm{NO}_{\mathrm{x}}$ and $\mathrm{NH}_{3}$ has tripled since 1860 and is expected to double again by 2050 (Galloway et al., 2004). These increases in $\mathrm{N}$-deposition have lead to increases in the $\% \mathrm{~N}$ of soils, decreases in the $\mathrm{C}: \mathrm{N}$ of biomass, and an increase in $\mathrm{NO}_{3}^{-}$ of surface waters in ecosystems of the Western US (Baron et al., 2000; Fenn et al., 2003). Because $\mathrm{N}$ is often delivered as wet deposition (Galloway et al., 2004) it is easily transformed to $\mathrm{HNO}_{3}$ that can also lead to soil acidification and increased bedrock weathering. However, the susceptibility and resilience of aquatic ecosystems to changes in $\mathrm{pH}$ resulting from acid deposition is highly dependent on their acid neutralizing capacity (Schindler et al., 1986). One

Published by Copernicus Publications on behalf of the European Geosciences Union. 
potential source of acid neutralizing capacity is atmospheric dust (Psenner, 1999), which may help explain relatively constant $\mathrm{pH}$ values across $\mathrm{N}$-deposition gradients in the US (Baron et al., 2000). Therefore increased $\mathrm{N}$ deposition may lead to increases in primary productivity and acidification, but these effects may vary based on the elemental composition of atmospheric deposition and watershed bedrock.

Atmospheric deposition of dust is also very important in regulating global biogeochemical cycles (Lambert et al., 2008). In fact, the strong correspondence between increased dust emissions and glacial cycles has been hypothesized as a mechanism delivering nutrients to the ocean and regulating concentrations of atmospheric $\mathrm{CO}_{2}$ over glacial timescales (Martin, 1990). Although cooler temperatures and widespread aridity are thought to have promoted dust emissions during glacial intervals (Lambert et al., 2008), the mechanisms controlling dust emissions on shorter timescales are less well known. The correspondence between regional drought and dust emissions from the Sahel has been well documented (Prospero and Lamb, 2003); however, this interannual variability is superimposed on a decadal scale increase in dust emissions due to the intensification of regional agriculture (Mulitza et al., 2010). Similar increases in dust emissions have been identified in the arid southwestern US in response to increased livestock grazing (Neff et al., 2008). Although the direct and indirect physical impacts of aerosols on the atmosphere have been well studied, the role that aerosols play as nutrient vectors has received much less attention. A global analysis of dust measurements has revealed that dust is typically enriched in nutrients, such as $\mathrm{P}$, $\mathrm{Ca}, \mathrm{Mg}, \mathrm{K}$ (Lawrence and Neff, 2009). It has also been suggested that human activity has resulted in a $30-50 \%$ increase in total P deposition in perturbed regions of North America, Asia, and Africa (Mahowald et al., 2008). Therefore, recent changes in dust emissions have affected the biogeochemical cycles of phosphorus and other elements at regional to global scales.

Relative changes in the deposition of $\mathrm{N}$ and $\mathrm{P}$ can have impacts on ecosystem function and composition. The relationship between atmospheric $\mathrm{N}$ deposition and nutrient limitation has been verified for a large number of Northern Hemisphere lakes, where high levels of $\mathrm{N}$ deposition lead to P-limited primary productivity (Elser et al., 2009). However, much less research has focused on the extent to which changes in $\mathrm{P}$ deposition have altered ecosystem processes (but see Morales-Baquero et al., 1999). Several recent studies have investigated the impacts of dust deposition on modern ecosystem processes. Alpine watersheds located in Southern Europe receive large amounts of $\mathrm{N}$ in wet deposition and high amounts of $\mathrm{P}$ in dry dust deposition from the Sahel (Morales-Baquero et al., 2006). This enhanced P deposition from dust has been shown to increase primary productivity and alter species composition in many Mediterranean lakes (Morales-Baquero et al., 2006; Reche et al., 2009). However, much less is known about changes in the rela- tive deposition of N:P over time in these alpine watersheds. Furthermore, physical and chemical differences in watershed properties may dampen or amplify the impact of $\mathrm{N}$ and $\mathrm{P}$ deposition on alpine ecosystems. For instance, lakes with larger watershed areas may be more susceptible to nutrient loading from the atmosphere and lakes located in watersheds with little or no $\mathrm{P}$ present in their bedrock may show a greater response to increased atmospheric P-loading.

Here we build upon previous observations that an increase in human activity has lead to an increase in dust emissions in the Western US (Neff et al., 2008). In particular, we investigate the biogeochemical consequences of changes in dust deposition in alpine ecosystems adjacent to regions of known dust emission. We investigate changes in the biogeochemical response of two watersheds located in the San Juan Mountains (SJM) of Southern Colorado by analyzing lake sediment cores from their catchments. First, we establish recent changes in the physical flux of dust to these systems by estimating mass accumulation rates based on radionuclide dates and density estimates. We then apply geochemical techniques to lake sediments, atmospheric dust, and watershed bedrock to partition sediment fluxes between local endogenous sources (i.e. bedrock) and regional exogenous sources (i.e. dust). Lastly, we investigate how these changes in the physical flux and chemical composition of dust has impacted the productivity and species composition of these ecosystems. Although both of these watersheds experienced significant increases in dust deposition, the biogeochemical response of these ecosystems was mediated by physical and chemical differences in watershed properties.

\section{Study sites and methods}

\subsection{Study sites and sample collection}

For this study we sampled two alpine watersheds in the SJM $\left(37^{\circ} 50^{\prime} \mathrm{N}, 107^{\circ} 36^{\prime} \mathrm{W}\right)$, which lie directly downwind of the Colorado Plateau, a known dust source region (Simonson, 1995) (Fig. 1). The underlying geology of the SJM has been shaped by Cretaceous plutonic activity, Tertiary volcanic activity, and glacial retreat approximately $12000 \mathrm{yr}$ ago. Within the SJM we selected two watersheds, - Porphyry $\left(37^{\circ} 53^{\prime} 4.399^{\prime \prime} \mathrm{N}, 107^{\circ} 45^{\prime} 0.510^{\prime \prime} \mathrm{W}\right)$ and Senator Beck $\left(37^{\circ} 51^{\prime} 47.463^{\prime \prime} \mathrm{N}, 107^{\circ} 45^{\prime} 14.056^{\prime \prime} \mathrm{W}\right)$ - based on their high elevations $(\sim 3700 \mathrm{~m})$, lack of upslope soils and vegetation, and their volcanic bedrock that is geochemically distinct from aeolian dust (Lawrence et al., 2010; Neff et al., 2008).

Although these two alpine lakes were underlain by similar bedrock, the watershed dimensions and surface water chemistry were very different. Both lakes were approximately $2 \mathrm{~m}$ deep, but Porphyry had a much larger surface area and watershed area than Senator Beck. The overall watershed area to surface area ratio of Porphyry $\left[165910\left(\mathrm{~m}^{2}\right) / 6920\left(\mathrm{~m}^{2}\right)=24\right]$ was almost double that of 


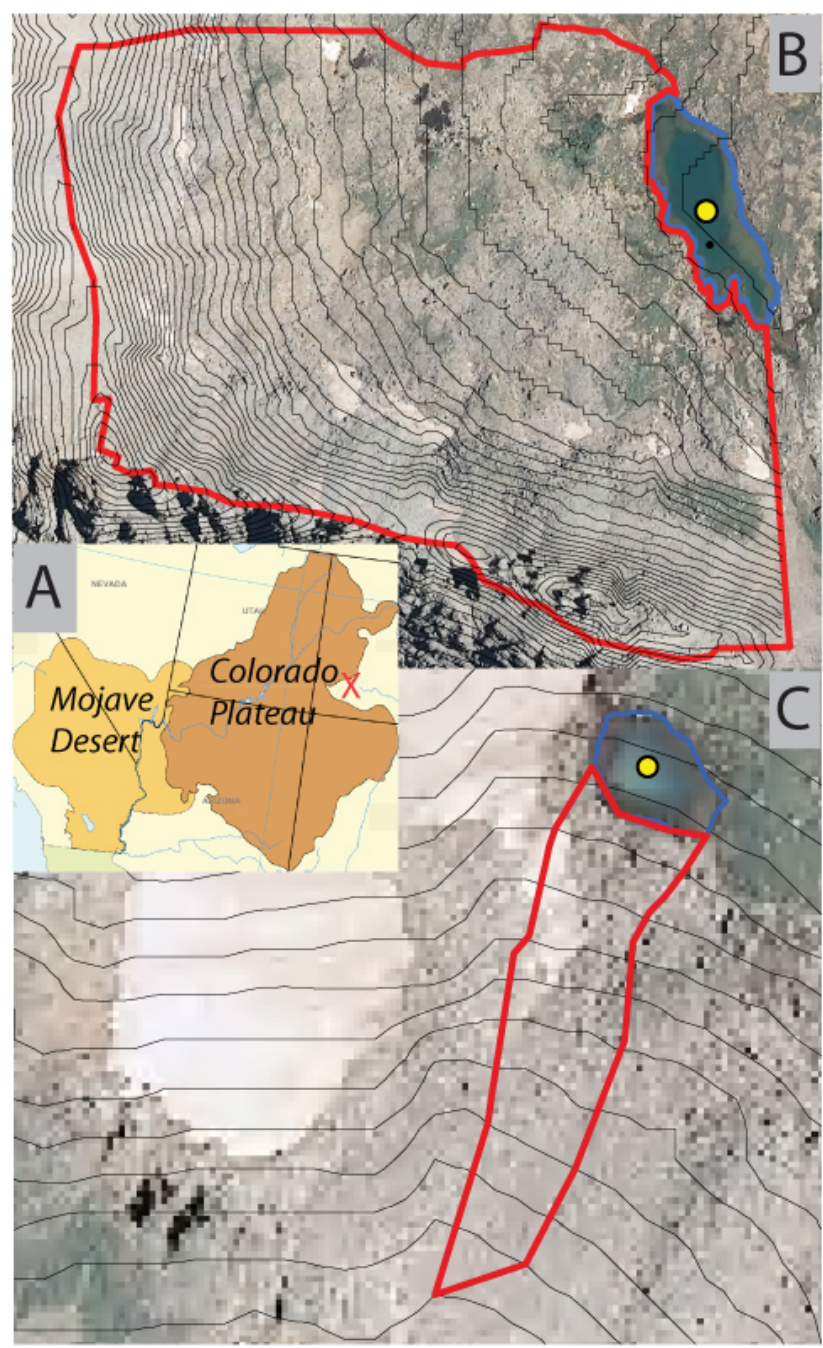

Fig. 1. Location of watersheds investigated in this study. The alpine watersheds investigated in this study are located in the San Juan Mountains (red X) directly downwind of the Mojave Desert and the Colorado Plateau (A). Lake sediment cores (yellow points) were collected from Porphyry (B) and Senator Beck (C) lake basins. The perimeter of each lake sampled is delineated in blue and the perimeter of each watershed is delineated in red. Contour lines (thin black lines) at $10 \mathrm{~m}$ intervals were used to estimate watershed area using ArcGIS (see methods). Green patches in orthophotos represent vegetation, grey patches represent talus slopes, and white patches represent seasonal snow cover with discoloration due to dust deposition. Note differences in scale of the two watersheds and morphometric parameters for each watershed reported in Table 4.

Senator Beck $\left[1420\left(\mathrm{~m}^{2}\right) / 110\left(\mathrm{~m}^{2}\right)=13\right]$. Based on in situ measurements made with a multi-sensor probe (YSI, Yellow Springs Ohio, USA) and surface water samples collected and analyzed by ion chromatography (DX-500, Dionex Corporation, Sunnyvale, CA). Porphyry was more basic $(\mathrm{pH}=8.0)$ with greater concentrations of both cations and anions and greater concentrations of $\mathrm{NO}_{3}^{-}$, whereas Senator Beck was more acidic $(\mathrm{pH}=7.0)$ but higher concentrations of $\mathrm{PO}_{4}^{-3}$ in the surface waters (Table 1).

Sediment cores were extracted from depth in both lakes $(\sim 1.5 \mathrm{~m})$ in July, 2006 using a Universal Corer (Fig. 1). Both lakes were fed by surface drainage with clear inlets that were avoided during sediment coring. Although there are numerous processes that may disturb sedimentation (Catalan, 1989), neither core showed evidence of sediment disturbance (Fig. 1). Both sediment cores were transported to the laboratory on ice and extruded at a high resolution ( 0.5 to $1.0 \mathrm{~cm}$ ) for geochemical analyses, and dating using ${ }^{210} \mathrm{~Pb}$ of bulk sediments and ${ }^{14} \mathrm{C}$ dating of plant macrofossils. Four representative bedrock samples were collected from within each watershed for geochemical analyses. The outer weathering rind of all bedrock samples was first removed using a rock saw and then samples were pulverized using a shatterbox to yield homogenized samples. Both the weathering rind and the inner rock were analyzed for major and trace elemental composition and only the inner rock was analyzed for rare earth isotopes. Lastly, a total of 30 widespread discrete dust deposition events $\left(\bar{\chi}=1.3 \mathrm{~g} \mathrm{~m}^{-2} ; \sigma=0.9 \mathrm{~g} \mathrm{~m}^{-2}\right)$ were identified and characterized in the snowpack between 2003 and 2007 (Supplement Fig. S1). Samples were typically collected within 2 to 3 days of deposition. Snowpack samples were melted, evaporated and then freeze dried prior to geochemical analysis, according to Lawrence et al. (2010). Each discrete dust event was analyzed for both major and trace elemental composition and a subset of 6 dust events from 2005 and 2006 were analyzed for rare earth isotopes.

\subsection{Dating of lake sediments}

Surface sediment samples were dated using ${ }^{210} \mathrm{~Pb}$ and sediments at depth were dated using ${ }^{14} \mathrm{C} .{ }^{210} \mathrm{~Pb}$ is continuously produced from the decay of ${ }^{222} \mathrm{Rn}$ gas in the atmosphere and because it has a half-life of $\sim 22 \mathrm{yr}$ it is suitable for dating sediments up to $\sim 150 \mathrm{yr}$ old. Bulk surface samples were digested and spiked with ${ }^{210} \mathrm{Po}$ and decay rates were estimated using an alpha spectrometer, according to the method described by DeMaster et al. (1985). Unsupported ${ }^{210} \mathrm{~Pb}$ activity levels were estimated for 12 samples per sediment core and sediment accumulation rates were calculated using the constant rate of supply model (Appleby and Oldfield, 1983). For dating older sediments, plant macrofossils were identified and removed from the sediments. These samples were rinsed, sonicated, and then freeze dried prior to analysis for ${ }^{14} \mathrm{C}$ content using the Keck-Carbon Cycle Accelerator Mass Spectrometer at UC Irvine. An oxalic acid standard of known ${ }^{14} \mathrm{C}$ content was analyzed to ensure the precision of dates (Neff et al., 2008). Because ${ }^{14} \mathrm{C}$ has a much longer half-life $(5730 \mathrm{yr})$ than ${ }^{210} \mathrm{~Pb}(22 \mathrm{yr})$ there is a notable gap in our dating techniques between our last reliable ${ }^{210} \mathrm{~Pb}$ dates $(147 \pm 19$ and $210 \pm 33)$ and our first reliable ${ }^{14} \mathrm{C}$ dates $(3138 \pm 30$ and $1163 \pm 29)$. To infer changes in sediment accumulation during this interval of uncertainty piecewise 
Table 1. Physical and Chemical properties of lakes investigated in this study, including depth, area, $\mathrm{pH}$, dissolve oxygen and Ion concentration. Ion concentrations represent average surface values from a single day in August 2006 when cores were extracted.

\begin{tabular}{|c|c|c|c|c|c|c|c|c|c|c|c|c|c|c|c|c|}
\hline \multirow[b]{2}{*}{ Alpine Lakes } & \multirow{2}{*}{$\begin{array}{l}\text { Depth } \\
\text { (m) }\end{array}$} & \multirow{2}{*}{$\begin{array}{l}\text { Lake } \\
\text { Area } \\
\left(\mathrm{m}^{2}\right)\end{array}$} & \multirow{2}{*}{$\begin{array}{r}\text { Watershed } \\
\text { Area } \\
\left(\mathrm{m}^{2}\right)\end{array}$} & \multirow{2}{*}{$\begin{array}{l}\text { Dissolved } \\
\text { Oxygen } \%\end{array}$} & \multirow{2}{*}{$\begin{array}{c}\mathrm{pH} \\
-\log \left[\mathrm{H}^{+}\right]\end{array}$} & \multicolumn{6}{|c|}{ Cations $\left(\mu \mathrm{eq} 1^{-1}\right)$} & \multicolumn{5}{|c|}{ Anions $\left(\mu \mathrm{e}^{-1}\right)$} \\
\hline & & & & & & $\mathrm{Li}^{+}$ & $\mathrm{Na}^{+}$ & $\mathrm{NH}_{4}^{+}$ & $\mathrm{K}^{+}$ & $\mathrm{Mg}^{+2}$ & $\mathrm{Ca}^{+2}$ & $\mathrm{~F}^{-}$ & $\mathrm{Cl}^{-}$ & $\mathrm{SO}_{4}^{-2}$ & $\mathrm{NO}_{3}^{-}$ & $\mathrm{PO}_{4}^{-3}$ \\
\hline Porphyry & 2.0 & 6920 & 165910 & 74.68 & 8.0 & 0.1 & 31.5 & 1.5 & 8.5 & 47.7 & 591.5 & 3.3 & 0.9 & 675.5 & 6.2 & 0.0 \\
\hline Senator Beck & 1.8 & 110 & 1420 & 72.51 & 7.0 & 0.0 & 30.9 & 0.7 & 4.0 & 27.7 & 644.2 & 1.1 & 0.7 & 81.4 & 0.8 & 3.1 \\
\hline
\end{tabular}

spline functions were fit to the age-depth relationship and the first derivative of these spline functions was calculated as an estimate of changes in sedimentation rate $\left(\mathrm{cm} \mathrm{yr}^{-1}\right)$ over time (see Sect. 2.4). These continuous functions of changes in sedimentation rate were then multiplied by sediment density $\left(\mathrm{g} \mathrm{cm}^{-3}\right)$ in order to calculate changes in sediment accumulation rate $\left(\mathrm{g} \mathrm{cm}^{-2} \mathrm{yr}^{-1}\right)$. Changes in density for each sediment core were measured at the Limnological Research Center Core Facility at the University of Minnesota using a Geotek Multi-Sensor Core Logger, spurious density measurements at the sediment-water interface were not included in our mass accumulation calculations. Instrumental precision was between 0.01 and $0.05 \mathrm{~g} \mathrm{~cm}^{-3}$ and cores were logged at a $0.3 \mathrm{~mm}$ resolution.

\subsection{Biogeochemical analyses}

All sediment, dust, and bedrock samples were analyzed for elemental composition to identify the enrichment or depletion of elements in lake sediments relative to potential sources. Homogenized samples were treated with a series of digestions using $\mathrm{HNO}_{3}, \mathrm{HClO}_{4}$, and $\mathrm{H}_{2} \mathrm{O}_{2}$, followed by a microwave assisted digestion using $\mathrm{HF}$ and $\mathrm{HCl}$ to yield the inorganic fraction of each sample. The inorganic fraction of each sample was then analyzed for an array of elements using both Inductively Coupled Plasma Atomic Emission Spectroscopy (ICP-AES, ARL 3410+) and Inductively Coupled Plasma Mass Spectroscopy (ICP-MS, Perkin Elmer Elan DRC-E) at the Laboratory for Environmental Geoscience at CU Boulder. Two bedrock standards - Hawaiian Basalt (USGS BHVO-2) and Silver Plume Granodiorite (USGS GSP-2) - were also included in each extraction yielding an estimated error of $<8 \%$ across all major elements. Elemental composition of the outer weathering rind and the inner unaltered bedrock were both analyzed and no significant difference in elemental composition was observed (t-tests; $\mathrm{p}$ values $>0.11$ ) and thus elemental values from bedrock samples were combined. We also analyzed 5 duplicate samples across both sediment cores and coefficients of variation ranged between $3 \%$ and $16 \%$ among all elements. Phosphorus is not lost during this digestion therefore elemental $\mathrm{p}$-values from this analysis represent the total sediment fraction, including organic and inorganic $\mathrm{P}$.
Sediments were also analyzed for $\mathrm{C}$ and $\mathrm{N}$ as well as stable carbon $\left(\delta^{13} \mathrm{C}\right)$ and stable nitrogen $\left(\delta^{15} \mathrm{~N}\right)$ isotopes in the organic fraction. Sediment samples were treated with $10 \%$ $\mathrm{HCl}$ to remove the carbonate fraction and elemental carbon and nitrogen were measured using a Carlo Erba Elemental Analyzer and $\delta^{13} \mathrm{C}$ and $\delta^{15} \mathrm{~N}$ were measured using a Finnigan MAT Delta Plus XL mass spectrometer at the Duke Environmental Isotope Laboratory. All samples were analyzed in combination with Acetanilide, cellulose, sucrose, and urea standards yielding an analytical error of $\sigma=0.2 \%$. All isotopic data are reported as $\delta$ values, defined as $\delta=$ $\left(\frac{R}{R_{\mathrm{st}}-1}\right) \cdot 1000$ where $R$ is the ratio of isotopes in the sample and $R_{\mathrm{st}}$ is the ratio of isotopes in the standard. For carbon isotopes $\left(\delta^{13} \mathrm{C}\right)$ all values are reported with respect to the Vienna Pee Dee Belemnite (VPDB) standard $\left(R_{\mathrm{st}}=1.12372 \times 10^{-2}\right)$ and for nitrogen isotopes $\left(\delta^{15} \mathrm{~N}\right)$ all values are reported with respect to the atmospheric $\mathrm{N}_{2}$ standard $\left(R_{\mathrm{st}}=3.68 \times 10^{-3}\right)$. The stable isotopic composition of organic carbon is often used as a proxy of primary productivity in aquatic ecosystems, with increases in isotopic enrichment often used as an indicator of increased primary productivity (O'Reilly et al., 2003). However, the $\delta^{13} \mathrm{C}$ of atmospheric $\mathrm{CO}_{2}$ has also varied over the Holocene and more recently as a result of fossil fuel combustion (Francey et al., 1999), therefore all $\delta^{13} \mathrm{C}$ values of organic carbon $\left(\delta_{\mathrm{O}}\right)$ are expressed as discrimination against atmospheric $\mathrm{CO}_{2}\left(\delta_{\mathrm{a}}\right)$, based on the discrimination equation $\Delta^{13} \mathrm{C}=\left(\delta_{\mathrm{a}}-\delta_{\mathrm{o}}\right) /\left(1+\delta_{\mathrm{o}}\right)$ of Farquhar et al. (1989).

A subset of sediment, dust, and bedrock samples were also analyzed for isotopic composition of Strontium (Sr), Samarium (Sm), and, Neodynium (Nd) to identify potential sources of allochtonous material to lake sediments. These rare earth elements often have unique concentrations and isotopic compositions in different geologic substrates and can be useful in distinguishing between allochtonous calcareous dust and autochthonous volcanic bedrock. For Senator Beck sediments, two size classes were analyzed- the $37-60 \mu \mathrm{m}$ size class which most closely resembles the particle size distribution of eolian dust (Neff et al., 2008) and the over $250 \mu \mathrm{m}$ size class at 4 different depths $-2 \mathrm{~cm}, 6 \mathrm{~cm}, 15 \mathrm{~cm}$, and $23 \mathrm{~cm}$. For Porphyry only the total size fraction was analyzed for 3 depths $-5 \mathrm{~cm}, 12 \mathrm{~cm}$, and $20 \mathrm{~cm}$. The inner rock of all 8 bedrock samples and a total of 7 dust events were analyzed for rare earth isotopes. Following the removal of 
ammonium-acetate-soluble material, samples were digested in a concentrated $\mathrm{HF}$ and $\mathrm{HClO}_{4}$ solution and then evaporated to dryness. For $\mathrm{Sr}$ analysis, samples were added to $0.5 \mathrm{ml}$ of $2 \mathrm{~N} \mathrm{HNO}_{3}$ in a Teflon column containing $\sim 500 \mathrm{mg}$ of $\mathrm{Sr}$ resin (Eichrom Technologies, Lisle, IL). These columns were then eluted with a total of $1.6 \mathrm{ml}$ of $2 \mathrm{~N} \mathrm{HNO}_{3}$ and $3 \mathrm{ml}$ of $7 \mathrm{~N} \mathrm{HNO}_{3}$. Strontium samples were then collected in $1.5 \mathrm{ml}$ of $0.5 \mathrm{~N} \mathrm{HNO}_{3}$ eluent for analysis. For $\mathrm{Nd}$ analysis, samples were eluted on a Teflon column with $1.6 \mathrm{ml}$ of $2 \mathrm{~N}$ $\mathrm{HNO}_{3}$ and then with $2 \mathrm{ml}$ of $0.05 \mathrm{HNO}_{3}$, which was collected in a clean Teflon vessel. These samples were evaporated to dryness, added to a calibrated glass-resin column in $50 \mu \mathrm{l}$ of $0.25 \mathrm{~N} \mathrm{HCL}$, and Nd was collected with 0.25 N HCL. Lastly, ${ }^{87} \mathrm{Sr} /{ }^{86} \mathrm{Sr}$ and ${ }^{143} \mathrm{Nd} /{ }^{144} \mathrm{Nd}$ measurements were made using a Finnigan-MAT 261 thermal ionization mass spectrometer at the University of Colorado Radiogenic Isotope Laboratory. Analytical blanks included in the procedure averaged $\sim 1 \mathrm{ng}$ of $\mathrm{Sr}$ and $\sim 100 \mathrm{pg}$ of $\mathrm{Nd}$. Thirty measurements of the $\mathrm{Sr}$ standard (SRM-987) during the study period yielded a mean ${ }^{87} \mathrm{Sr} /{ }^{86} \mathrm{Sr}=0.71032 \pm 2$ and all reported ${ }^{87} \mathrm{Sr} /{ }^{86} \mathrm{Sr}$ values are corrected to the SRM-987 value of 0.71028 . Thirty three measurements of the La Jolla $\mathrm{Nd}$ standard during the study period yielded a mean ${ }^{143} \mathrm{Nd} /{ }^{144} \mathrm{Nd}=0.511838 \pm 8(2$ $\sigma$ mean) and all reported ${ }^{143} \mathrm{Nd} /{ }^{144} \mathrm{Nd}$ values are normalized to ${ }^{143} \mathrm{Nd} /{ }^{144} \mathrm{Nd}=0.7219$. Values of ${ }^{147} \mathrm{Sm} /{ }^{144} \mathrm{Nd}$ are calculated with a reproducible precision of $0.5 \%$ based on multiple measurements of an internal laboratory standard (Farmer et al., 2002).

Sediments were also examined for relative changes in diatom abundance and composition. Approximately $0.3-0.5 \mathrm{~g}$ of wet sediment from each sample was treated with $10 \%$ $\mathrm{HCl}$ to remove carbonates, followed by $30 \% \mathrm{H}_{2} \mathrm{O}_{2}$ to remove organic material. The processed material was settled onto coverslips and mounted on slides with Naphrax ${ }^{\circledR}$. A minimum of 300 diatom valves were counted for each sample under oil immersion at a magnification of 1000X on an Olympus BX51 microscope with differential interference contrast. Diatom taxonomy was based on Krammer and Lange-Bertalot (1988) and Camburn and Charles (2000).

\subsection{Statistical and geospatial analyses}

The relationship between age, inferred from our radionuclide estimates, and depth of sediments was fit with a spline function and the derivative was calculated to estimate changes in sedimentation rate. The spline function was fit using the "smooth.spline" function (R, 2007). Spline functions were fit using an intermediate smoothing parameter of 0.5 and weighted by the inverse of the error for each date inferred from our radionuclide measurements. Thus the more modern and precise ${ }^{210} \mathrm{~Pb}$ dates were given more weight in the fitting process than the older and less precise ${ }^{14} \mathrm{C}$ dates.

For partitioning the allochthonous fluxes to our lake sediments we relied on the Bayesian mixing model developed by Parnell et al. (2010). This mixing model has advantages over conventional mixing models because it allows for multiple sources and multiple isotopes while providing posterior probability distributions rather than finite solutions for different sources. The model structure for inferring any number of sources $(k)$, in this case bedrock and dust, contributing to an observation of isotopic $(i)$ variability in a sample $(j)$, such that the observed values $\left(X_{i j}\right)$ in the sediment can be expressed as:

$$
X_{i j}=\frac{\sum_{k=1}^{K} p_{k} q_{k i} s_{k i}}{\sum_{k=1}^{K} p_{k} q_{k i}}+\varepsilon_{i j},
$$

where $p_{k}$ represents the proportions of $k$, contributing to $X_{i j}$, $q_{k i}$ represents the concentration of isotope $i$ in source $k, s_{k i}$ represents the isotopic value of source $k$ with a normal distribution of mean $\mu_{k i}$ and variance $\omega_{k i}^{2}$, and $\varepsilon_{i j}$ represents residual inter-sample error not described by the model. We have specified the Dirichlet distribution for the prior of $p_{k}$, which is essentially the multivariate generalization of the Beta distribution (Parnell et al., 2010). Posterior distributions of $p_{k}$ are then fit using a Markov chain Monte Carlo simulation. Multivariate models were evaluated based on optimizing coefficients of determination $\left(R^{2}\right)$ and minimizing Akaike's information criteria (AIC). Principal components analyses were also performed on changes in elemental concentrations with age for each watershed (R, 2007).

Morphometric properties of our study lakes and their watersheds were calculated using Arc-Map software (ArcGIS v. 9.3, ESRI, Redlands, CA). A handheld global positioning instrument was used to georeference both lakes. These georeferenced points were then overlaid onto orthophotos (USDA, 2010) in order to calculate lake surface area with the Arc-map measure tool. Interpolated $5 \mathrm{~m}$ digital elevation models (USGS, 2010) were used to calculate the watershed area of each lake with the spatial analyst hydrology tools in Arc-map. This was done by first determining water flow direction for each watershed with the flow direction tool. Once the flow direction was established and verified, a layer containing lake pour points was developed using the watershed tool. The lake watershed area rasters were then converted to shape files and their surface areas were estimated using spatial statistic tools in Arc-map.

\section{Results}

\subsection{Changes in the flux of dust to alpine catchments}

Both Porphyry and Senator Beck Lakes have experienced considerable changes in the mass flux to sediments in the recent past. Dates inferred from ${ }^{210} \mathrm{~Pb}$ in both sediment records indicate a much more rapid sedimentation rate in the last $\sim 150$ yr than during previous millennia (Figs. 2 and 3 ). In Porphyry, background sedimentation rates inferred from 


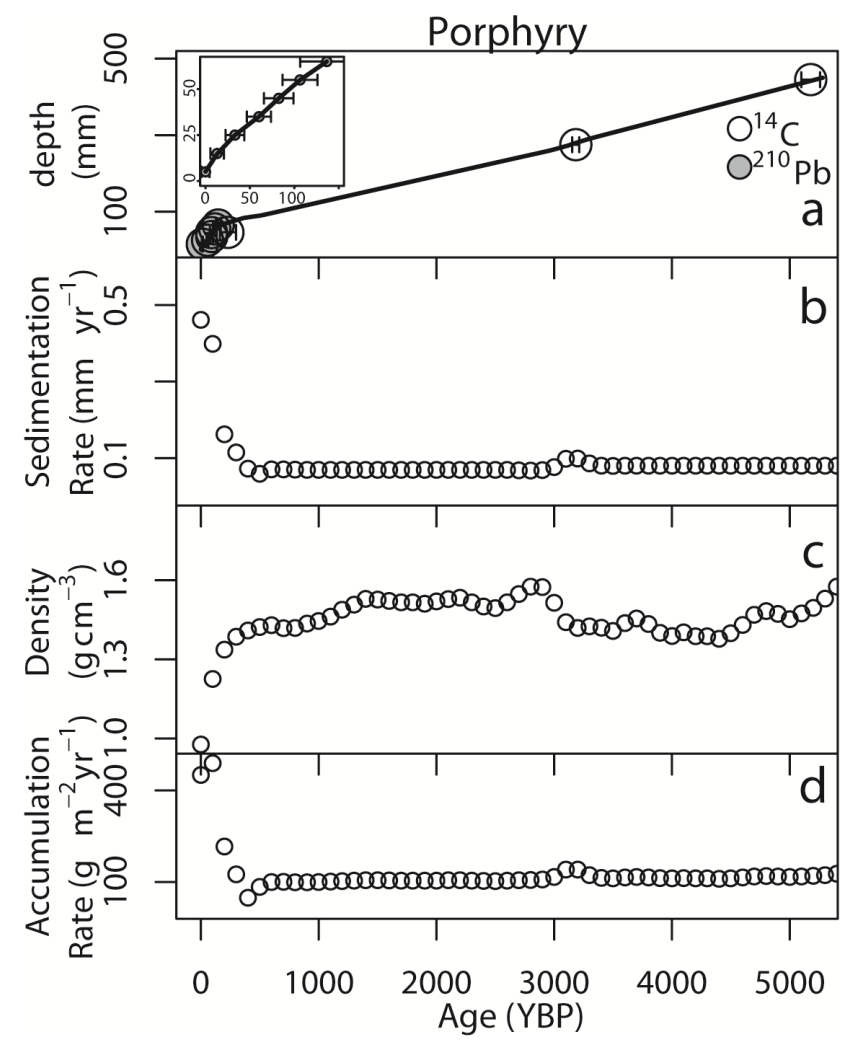

Fig. 2. Sediment accumulation rates for Porphyry Lake. Age depth relationship inferred from ${ }^{14} \mathrm{C}$ and ${ }^{210} \mathrm{~Pb}$ in sediments (a). A spline function (line) has been fit to both ${ }^{14} \mathrm{C}$ and ${ }^{210} \mathrm{~Pb}$ dates and the inset shows ${ }^{210} \mathrm{~Pb}$ in contemporary sediments (a). Sedimentation rates calculated as the first derivative of the spline function fit to the age-depth relationship (b). Changes in sediment density with depth (c) and mass accumulation rate calculated as the product of sedimentation rate and density (d).

${ }^{14} \mathrm{C}$ were approximately $0.1 \mathrm{~mm} \mathrm{yr}^{-1}$, but showed a significant increase to over $0.4 \mathrm{~mm} \mathrm{yr}^{-1}$ at (t-test; $\mathrm{p}$-value $=0.0008$; $\mathrm{DF}=6$ ) at some point since the Holocene (Fig. 2b). A similar significant increase is observed in Senator Beck (t-test; $\mathrm{p}$-value $=0.04 ; \mathrm{DF}=4)$, where sedimentation rates increased from approximately $0.06 \mathrm{~mm} \mathrm{yr}^{-1}$ to over $0.2 \mathrm{~mm} \mathrm{yr}^{-1}$ (Fig. 3b). Both lakes show an increase in sediment density with depth that one would expect as sediments become more compressed over time (Figs. 2c and 3c). Despite this increase in density with depth, both sediment records show a marked increase in contemporary mass accumulation rates compared to background mass accumulation rates (Figs. 2d and 3d). In Porphyry mass accumulation rates increased from $\sim 100 \mathrm{~g} \mathrm{~m}^{-2} \mathrm{yr}^{-1}$ to $\sim 500 \mathrm{~g} \mathrm{~m}^{-2} \mathrm{yr}^{-1}$ (Fig. 2d) and in Senator Beck mass accumulation rates increased from $\sim 100 \mathrm{~g} \mathrm{~m}^{-2} \mathrm{yr}^{-1}$ to $\sim 400 \mathrm{~g} \mathrm{~m}^{-2} \mathrm{yr}^{-1}$ (Fig. 3d). Although it is clear that these two lakes have experienced a 400 to $500 \%$ increase in the rate of mass accumulation; it is unclear how much of this increase can be attributed to atmospheric dust

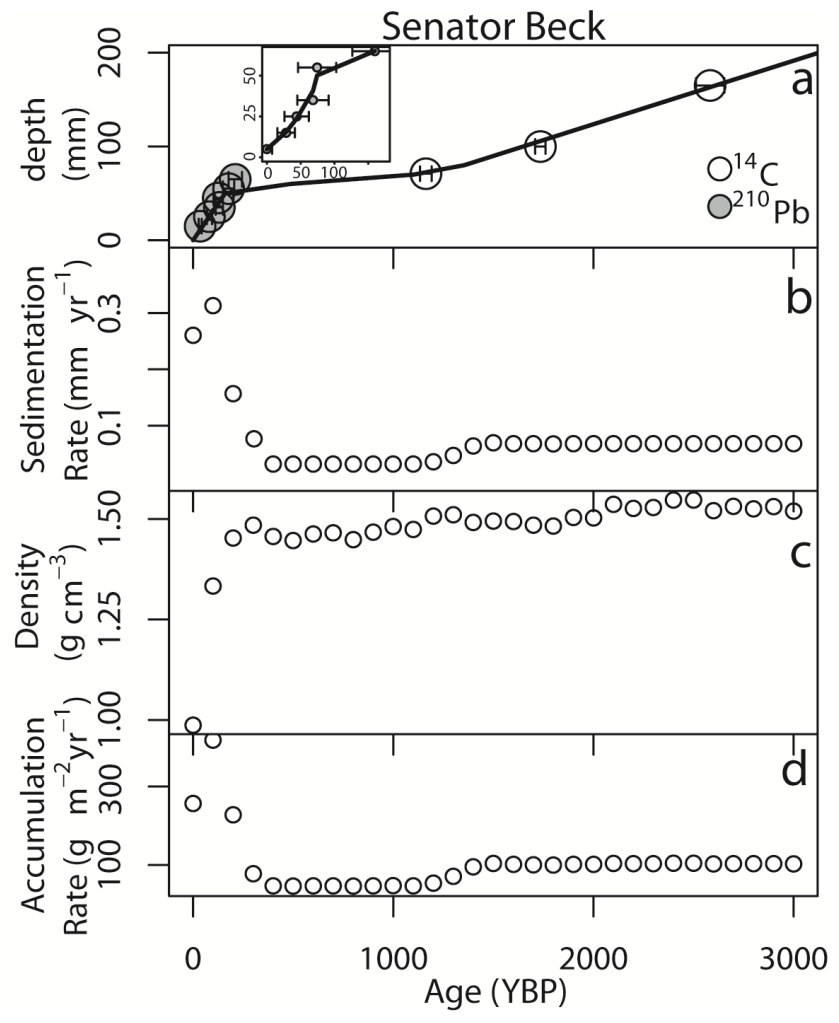

Fig. 3. Sediment accumulation rates for Senator Beck Lake. Age depth relationship inferred from ${ }^{14} \mathrm{C}$ and ${ }^{210} \mathrm{~Pb}$ in sediments (a). A spline function (line) has been fit to both ${ }^{14} \mathrm{C}$ and ${ }^{210} \mathrm{~Pb}$ dates and the inset shows ${ }^{210} \mathrm{~Pb}$ in contemporary sediments (a). Sedimentation rates calculated as the first derivative of the spline function fit to the age-depth relationship (b). Changes in sediment density with depth (c) and mass accumulation rate calculated as the product of sedimentation rate and density (d).

versus material derived from bedrock weathering in the watershed.

Based on the isotopic composition of inorganic material, sediments are primarily derived from atmospheric dust and to a lesser extent from bedrock weathering (Table 2). Despite the fact that bedrock material in the SJM tends to have a higher concentration of $\mathrm{Sr}$ than material blown in as atmospheric dust, ${ }^{87} \mathrm{Sr} /{ }^{86} \mathrm{Sr}$ values of sediments are almost indistinguishable from ${ }^{87} \mathrm{Sr} /{ }^{86} \mathrm{Sr}$ values of dust. Furthermore both size fractions analyzed for ${ }^{87} \mathrm{Sr} /{ }^{86} \mathrm{Sr}$ in Senator Beck were more similar to dust ${ }^{87} \mathrm{Sr} /{ }^{86} \mathrm{Sr}$ values and do not change appreciably with depth suggesting that dust has probably always been an important source of mass flux to these alpine watersheds (Supplement Fig. S2). Although concentrations of $\mathrm{Nd}$ and Sm did not differ that much between sediments, dust, and bedrock, isotopic ratios of ${ }^{143} \mathrm{Nd} /{ }^{144} \mathrm{Nd}$ and ${ }^{147} \mathrm{Sm} /{ }^{144} \mathrm{Nd}$ differed considerably in these substrates. In fact, sediment values of ${ }^{143} \mathrm{Nd} /{ }^{144} \mathrm{Nd}$ and ${ }^{147} \mathrm{Sm} /{ }^{144} \mathrm{Nd}$ were much more similar to dust than bedrock, with dust values 
Table 2. Trace element concentrations and isotopic compositions for sediments, dust, and bedrock. Sample sizes $(N)$ are indicated for sediments, dust and bedrock and all elemental and isotopic values are reported with their respective standard deviations in parentheses. Sediment samples are from both lakes at several depths and two different size fractions (see Supplement Fig. S2). These are the actual values used in our Bayesian mixing model (Eq. 1).

\begin{tabular}{lcccccc}
\hline Substrate & ${ }^{87} \mathrm{Sr} /{ }^{86} \mathrm{Sr}$ & $\mathrm{Sr}(\mathrm{ppm})$ & ${ }^{143} \mathrm{Nd} /{ }^{144} \mathrm{Nd}$ & $\mathrm{Nd}(\mathrm{ppm})$ & ${ }^{147} \mathrm{Sm} /{ }^{144} \mathrm{Nd}$ & $\mathrm{Sm}(\mathrm{ppm})$ \\
\hline Sediments $(N=11)$ & $0.71609(0.00109)$ & $104.06(17.95)$ & $0.51209(0.00001)$ & $19.77(2.84)$ & $0.10306(0.00260)$ & $3.32(0.44)$ \\
Dust $(N=6)$ & $0.71632(0.00301)$ & $114.98(25.67)$ & $0.51210(0.00001)$ & $13.86(1.06)$ & $0.10775(0.00171)$ & $2.47(0.21)$ \\
Bedrock $(N=8)$ & $0.70797(0.00587)$ & $252.34(22.25)$ & $0.51222(0.00005)$ & $40.87(9.40)$ & $0.11429(0.01255)$ & $4.05(5.60)$ \\
\hline
\end{tabular}

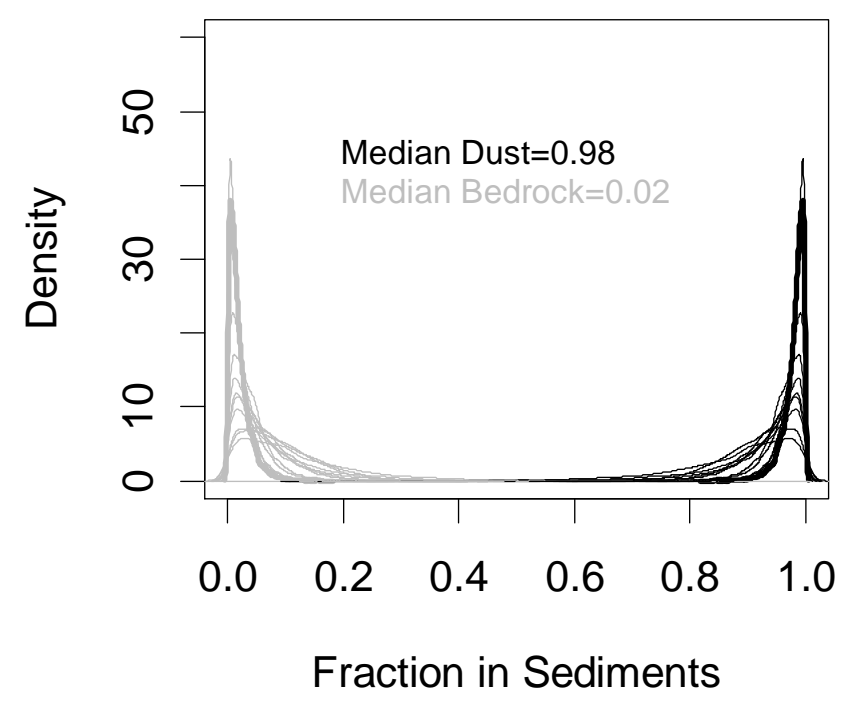

Fig. 4. Fraction of sediments derived from dust versus bedrock. Plotted are the probability density functions (PDFs) calculated from our mixing model. The thin lines correspond to the conventional two-end-member mixing models using all possible combinations of elemental concentrations and their isotopic values (Table 2). The thick lines represent the PDFs of sediment derived from bedrock versus dust when all isotopic tracers and their elemental concentrations are included in the mixing model. Based on this approach, approximately $98 \%$ of the sediment is derived from atmospheric dust and only $2 \%$ from local bedrock.

of ${ }^{143} \mathrm{Nd} /{ }^{144} \mathrm{Nd}$ and ${ }^{147} \mathrm{Sm} /{ }^{144} \mathrm{Nd}$ intermediate between sediment and bedrock values. These conservative isotopic tracers provide compelling evidence that sediments accumulated in these alpine watersheds largely reflect the geochemistry of dust being deposited in these alpine watersheds. This is verified by our mixing model simulations that indicate more than $95 \%$ of the inorganic material accumulated in these alpine lake sediments is derived from atmospheric dust and less than $5 \%$ is derived from bedrock weathering (Fig. 4).

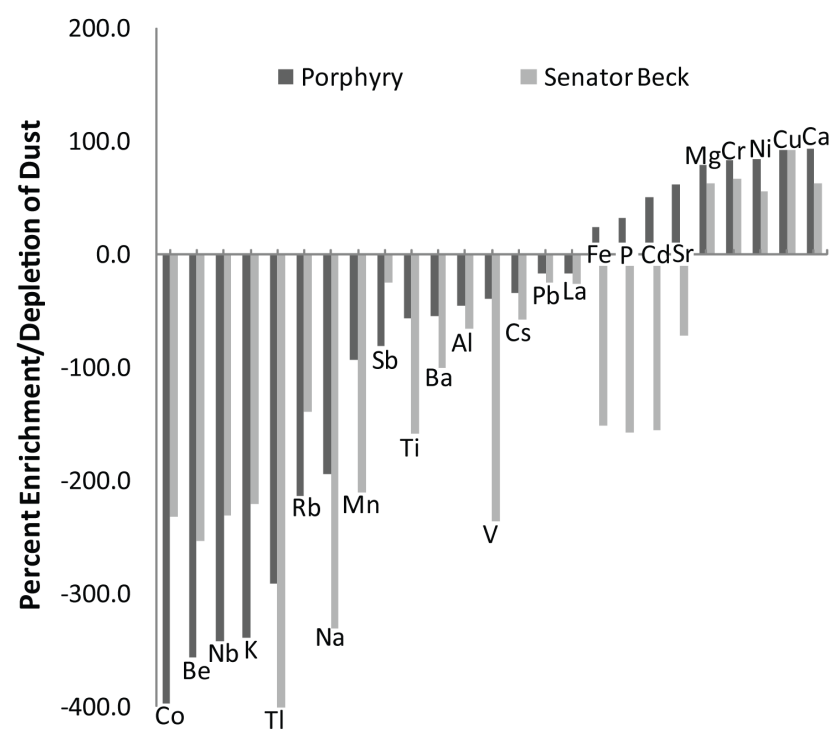

Fig. 5. Elemental concentrations of dust relative to local bedrock in the two watersheds. The elements that show greater concentration in bedrock relative to dust are shown as negatively depleted. The elements that show greater concentration in dust relative to bedrock are shown as positively enriched. Elements are plotted for both the Porphyryr (dark grey) and Senator Beck (light grey) watersheds.

\subsection{Geochemical composition of dust}

Dust samples were consistently enriched in some elements and consistently depleted in other elements with respect to bedrock elemental composition, but also showed some key differences between watersheds (Fig. 5). The elements that were consistently enriched in dust relative to bedrock in both watersheds were $\mathrm{Ca}, \mathrm{Cr}, \mathrm{Cu}, \mathrm{Mg}$, and $\mathrm{Ni}$. There was an abundance of elements that were consistently depleted in dust relative to bedrock in both watersheds, but some of the notable elements were $\mathrm{Al}, \mathrm{K}$, and $\mathrm{Mn}$. Lastly, there were several elements that showed inconsistent patterns of enrichment in dust with respect to the differing bedrock in the two watersheds (Fig. 5). Dust samples were enriched in $\mathrm{Fe}, \mathrm{Cd}, \mathrm{P}$, and $\mathrm{Sr}$ compared to bedrock in Porphyry, but dust samples were relatively depleted in these particular elements when compared 
to the bedrock chemistry of Senator Beck. The differential enrichment of elemental dust loading in these two watersheds may have important implications for biogeochemical cycling within these two watersheds.

An increase in fluxes of elements associated with dust is observed in the contemporary sediments from both watersheds. If we compare elemental concentrations in sediments to sediment dates based on our age model in a principal components analysis, we see that most of the variability observed over time can be explained by elements commonly associated with dust (Fig. 6). In Porphyry, most of the variance in elemental fluxes is explained by the first two principal components. Elements commonly associated with dust, such as $\mathrm{Si}, \mathrm{Na}, \mathrm{Mn}, \mathrm{K}, \mathrm{Al}$ and $\mathrm{Fe}$, contribute the most to the first principal component and other elements also associated with dust, such as $\mathrm{P}, \mathrm{Cu}$, and $\mathrm{Ca}$ contribute most to the second principal component in Porphyry (Fig. 6a). Elements such as $\mathrm{P}, \mathrm{Cu}, \mathrm{Ca}, \mathrm{Ni}$, and $\mathrm{Sr}$ are associated with contemporary sediments during the period of maximum accumulation rates due to dust inputs (Fig. 2). In contrast, most of the variance in elemental concentrations observed in Senator Beck can be explained by the first principle component (Fig. 6b). Elements that contributed most to this first principal component in Senator Beck were base cations, such as $\mathrm{Ca}, \mathrm{Mg}$, $\mathrm{Na}$, and $\mathrm{K}$, but also metals often associated with dust, such as $\mathrm{Cu}$, $\mathrm{Al}, \mathrm{Ti}$, and $\mathrm{Fe}$. Increases in $\mathrm{Ca}, \mathrm{Cd}, \mathrm{Cr}$, and $\mathrm{Ni}$ concentrations were associated with more contemporary sediments deposited during periods of maximum mass accumulation due to dust in Senator Beck (Fig. 3). There were also notable differences in patterns of $\mathrm{Cd}, \mathrm{Fe}, \mathrm{P}$, and $\mathrm{Sr}$, the four elements that were differentially enriched in dust with respect to the two watersheds (Fig. 5). In Porphyry these elements contributed more negatively to principle component 2 and were associated with fairly modern dates between 37 and $102 \mathrm{yr}$ before present (Fig. 6a). In contrast, in Senator Beck these elements contributed negative loadings to principle component 1 and tended to be associated with older dates.

\subsection{Biogeochemical response to changes in dust loading}

Although increases in dust loading are observed in both Porphyry and Senator Beck watersheds, the biogeochemical responses are quite different in these watersheds. A marked increase in the accumulation rate of organic carbon is evident in the modern sediments from both lakes (Fig. 7); however, the precise mechanisms driving these increases in organic carbon appear to be different in each lake. Both Porphyry and Senator Beck show proportional increases in the accumulation rates of $\mathrm{N}$ and $\mathrm{P}$ in modern sediments (Fig. 7). Although both lakes show similar patterns of $\mathrm{C}, \mathrm{N}$, and $\mathrm{P}$ accumulation rates, the concentration of these elements in sediments from Porphyry Lake are two to three times greater than sediments from Senator Beck (Figs. 7 and 8). Both lakes show steady declines in the $\mathrm{C}: \mathrm{N}$ ratio of sediments, with $\mathrm{C}: \mathrm{N}$ declining more precipitously in the modern sediments of Por-
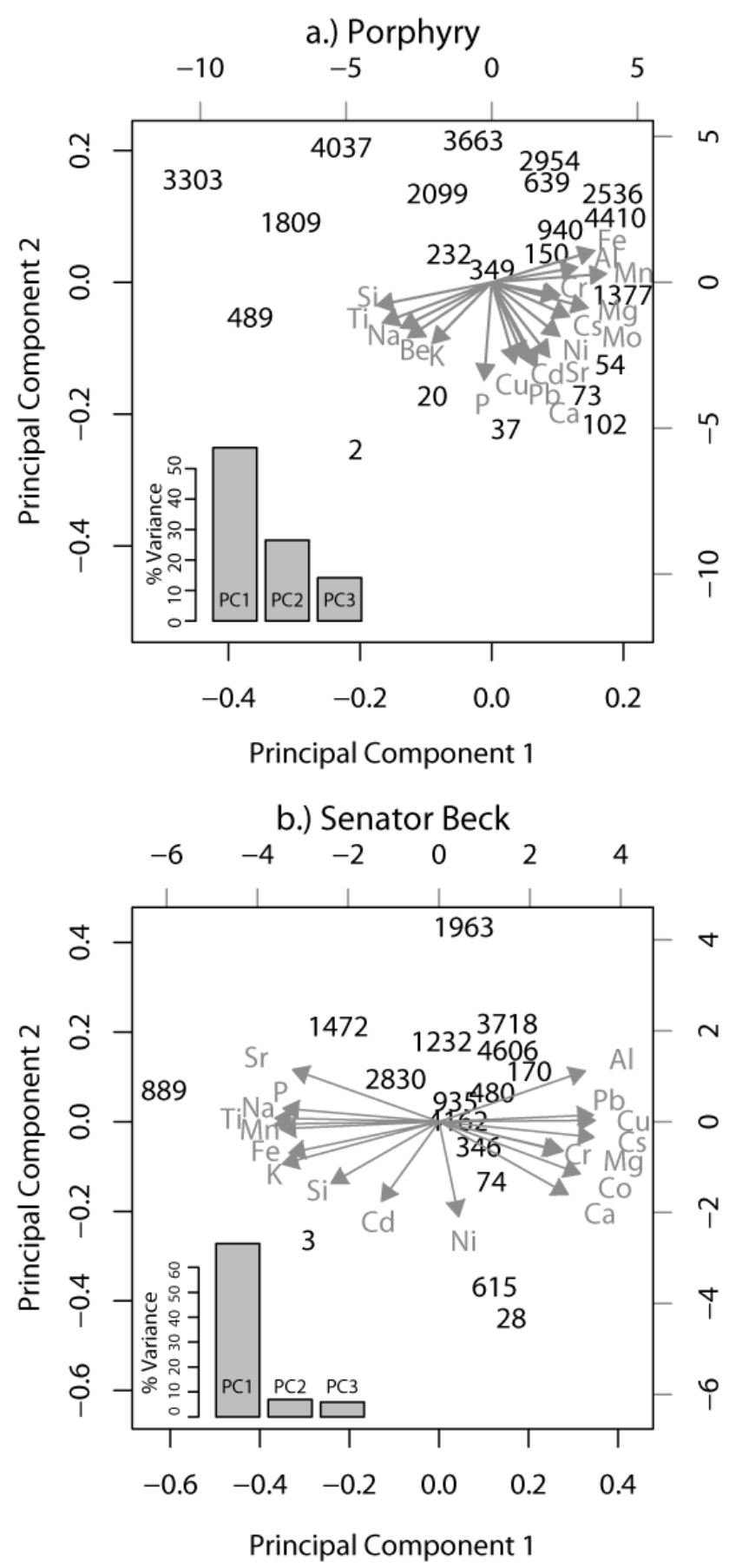

Fig. 6. Principal components analysis of elemental concentrations compared with dates plotted as years before present for lake sediments from Porphyry (a) and Senator Beck (b). Bi-plots identify the variance in elemental concentrations (grey arrows; top and right axes) that correspond with variance in age of sediments (black numbers; bottom and left axes). Inset grey bars in each figure show the amount of total variance in the array of data explained by the first 3 principal components (PC1, PC2, and PC3). 


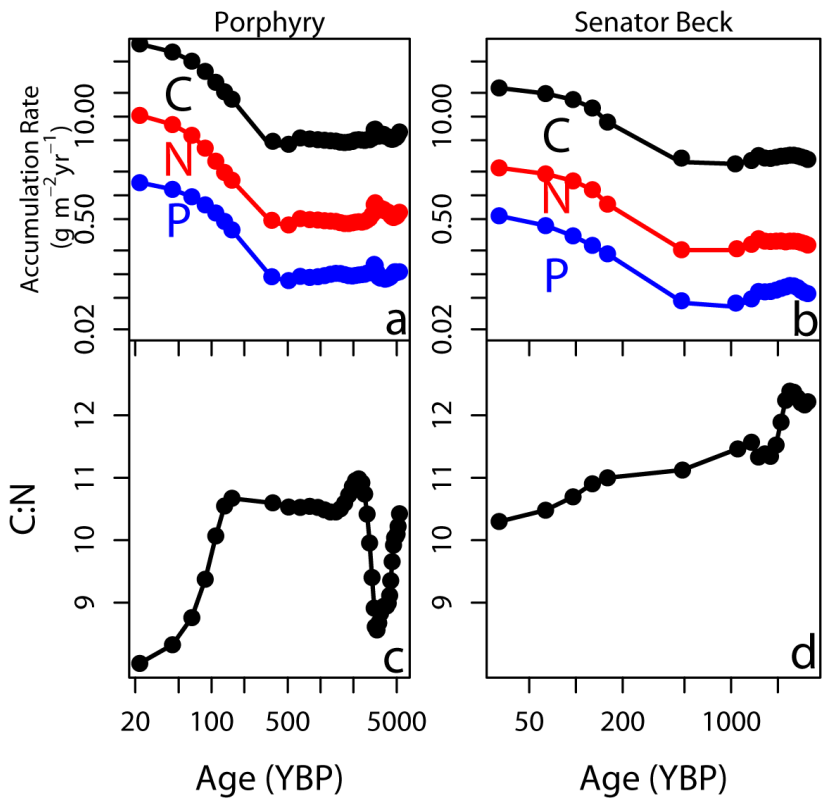

Fig. 7. Accumulation of carbon, nitrogen and phosphorus in the sediments of San Juan Lakes. Accumulation rates of C (black), $\mathrm{N}$ (red), and P (blue) are plotted for Porphyry (a) and Senator Beck (b). The mass ratios of C:N are plotted for Porphyry (c) and Senator Beck (d). Note the log scales of sediment age years before present (YBP) and the log scales for sediment accumulation rates to highlight contemporary sediment changes.

phyry (Fig. 7c and d). Increases in organic carbon in Porphyry (Table 3 ) are more responsive to increases in $\mathrm{N}$ concentration $\left(R^{2}=0.914 ; \mathrm{AIC}=55.36\right)$ than to increases in P concentration $\left(R^{2}=0.701 ; \mathrm{AIC}=118.89\right)$, with very little additional variance explained by correlation with $\mathrm{N}$ and $\mathrm{P}\left(R^{2}=0.915 ; \mathrm{AIC}=55.35\right)$. However, there is a much stronger response in organic $\mathrm{C}$ to $\mathrm{N}$ when $\mathrm{P}$ content exceeds $0.1 \%$ in Porphyry sediments (Fig. 8c). Increases in organic $\mathrm{C}$ content are also highly correlated with $\mathrm{N}$ content in Senator Beck $\left(R^{2}=0.956 ; \mathrm{AIC}=-60.19\right)$, but correlated to a lesser degree with $\mathrm{P}$ content $\left(R^{2}=0.335\right.$; $\left.\mathrm{AIC}=23.33\right)$. The relationship between organic $\mathrm{C}$ and organic $\mathrm{N}$ as well as $\mathrm{P}$ is much stronger $\left(R^{2}=0.968\right)$, as indicated by the reduced AIC (-68.51). Lastly, there appears to be a strong response in organic $\mathrm{C}$ content to $\mathrm{N}$ availability even when $\mathrm{P}$ is in short supply in Senator Beck (Fig. 8f).

In both Porphyry and Senator Beck Lake sediments there was a clear increasing trend in $\delta^{13} \mathrm{C}$ over the last $5000 \mathrm{yr}$ (Fig. 9) resulting in a clear decrease in $\Delta^{13} \mathrm{C}$ over the last $5000 \mathrm{yr}$ with a particularly strong decrease over the last 100 to $200 \mathrm{yr}$ in both lakes (Fig. 9c and f). Although there is considerable variability in $\delta^{15} \mathrm{~N}$ in the organic fraction of sediments in Porphyry $\left(1.5<\delta{ }^{15} \mathrm{~N}<4.0\right)$, there is no clear trend over time in response to dust loading to Porphyry (Fig. 9a). In contrast, Senator Beck shows a clear decline in $\delta^{15} \mathrm{~N}$ over the last $5000 \mathrm{yr}$ with $\delta^{15} \mathrm{~N}$ values in contemporary sed-
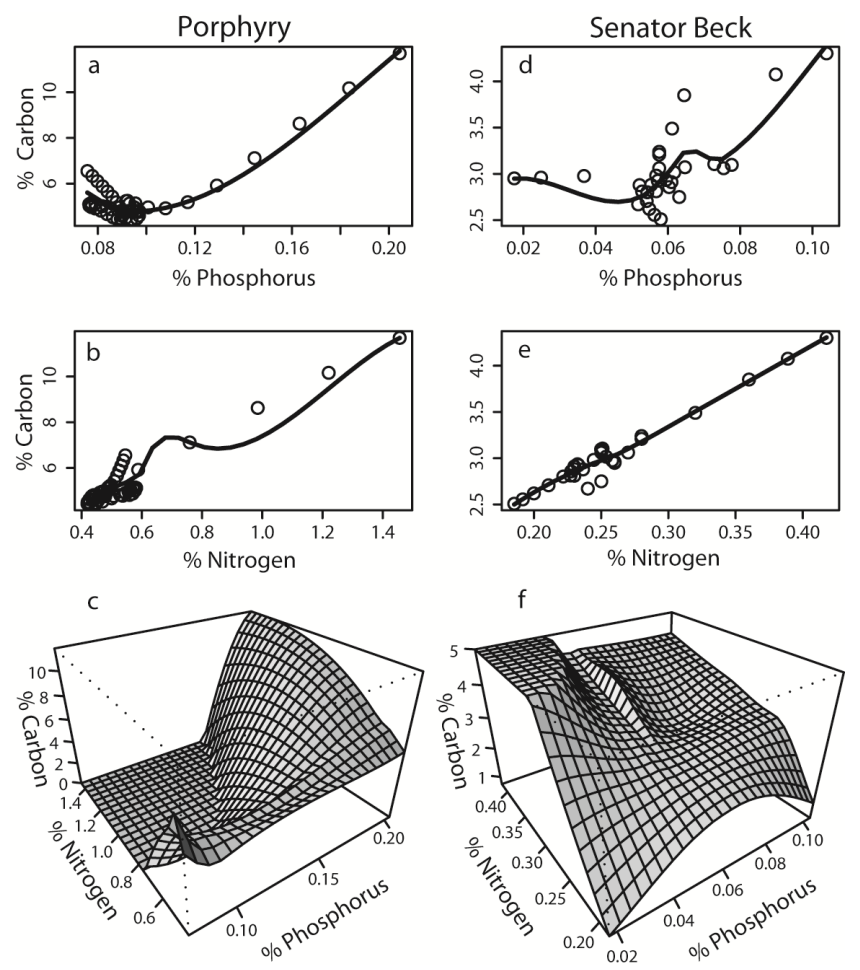

Fig. 8. The response of organic carbon content to nitrogen and phosphorus availability in the sediments of our two alpine lakes. The response of organic $\mathrm{C}$ to $\mathrm{N}$ and $\mathrm{P}$ in Porphyry Lake $(\mathbf{a}-\mathbf{c})$ is compared to the response of organic $\mathrm{C}$ to $\mathrm{N}$ and $\mathrm{P}$ in Senator Beck Lake (d-f). Top panels (a, b, d, and e) show the response of organic $\mathrm{C}$ to $\mathrm{N}$ and $\mathrm{P}$ respectively and bottom panels ( $\mathbf{c}$ and $\mathbf{f}$ ) show the response surfaces of organic to $\mathrm{N}$ and $\mathrm{P}$ simultaneously. Note the higher $\mathrm{C}$, $\mathrm{N}$, and $\mathrm{P}$ content in Porphyry as evidenced by the different scales.

iments showing the greatest change and approaching the atmospheric $\delta^{15} \mathrm{~N}$ value of 0 .

Changes in diatom assemblage provide independent evidence of major biological reorganization in response to increased dust loading to alpine watersheds of the SJM. Shifts in diatom species composition were observed in both cores. The most dominant species present in both sediment cores was Staurosirella pinnata (Ehrenberg) (Williams and Round, 1987), representing between 20 and $90 \%$ of the total diatom assemblage in any particular time interval (Fig. 10). Although $S$. pinnata is the most abundant diatom, it shows different trends in the two sediment cores. In Porphyry there is a gradual increasing trend in S. pinnata over the last $150 \mathrm{yr}$, with almost complete dominance by this taxon over the last $50 \mathrm{yr}$ (Fig. 10a). In contrast, S. pinnata has remained dominant and fairly constant in Senator Beck over the last $500 \mathrm{yr}$, with exception to the interval between 50 and $75 \mathrm{yr}$ ago when its relative abundance decreased by a factor of 2.5 (Fig. 10b). Both watersheds also show a different response in Navicula spp. In Porphyry, Navicula spp. peaked in abundance approximately $125 \mathrm{yr}$ ago and have since shown a gradual 
Table 3. Statistical relationships between organic carbon flux and nitrogen and phosphorus availability. All statistical models are general linear models of the form $\mathrm{C}=m \mathrm{~N}+m \mathrm{P}+b$, where the response in organic carbon (C) is expressed as a function of organic nitrogen $(\mathrm{N})$ and phosphorus $(\mathrm{P})$ availability and the slope coefficients $(m)$ are reported for both nutrients. Significant relationships are reported as p-values $<0.0001=* *$ and p-values $<0.001=*$, with their respective $R^{2}$ values. For multi-variate regressions the multiple $R^{2}$ value is reported. Akaike's Information Criteria (AIC) is also reported to evaluate the goodness of fit when additional model parameters are added.

\begin{tabular}{lccrc}
\hline Lake Basin & Nitrogen & Phosphorus & AIC & $R^{2}$ \\
\hline Porphyry: & $6.98 * *$ & & 55.36 & 0.914 \\
& & $44.91 * *$ & 118.89 & 0.701 \\
& $6.32 * *$ & 5.74 & 55.35 & 0.919 \\
& & & & \\
\hline Senator Beck: & $7.62 * *$ & & -60.19 & 0.956 \\
& & $15.32 * *$ & 23.33 & 0.335 \\
& $7.10 * *$ & $3.32 *$ & -68.51 & 0.968 \\
\hline
\end{tabular}

decline in abundance (Fig. 10a). On the other hand, Navicula spp. in Senator Beck are less than $10 \%$ of the assemblage over the last $500 \mathrm{yr}$, except for a peak at approximately $25 \%$ of the total diatom abundance roughly $75 \mathrm{yr}$ ago (Fig. 10b). The one diatom species that shows a coherent response in both watersheds is Achnanthidium minutissimum (Kützing) Czarnecki, which is a fairly prevalent taxon in the SJM region (Sgro et al., 2007). In both watersheds a gradual increase in the relative abundance of $A$. minutissimum has been observed with a peak in abundance between 50 and $75 \mathrm{yr}$ ago, followed by a decline and then a subsequent increase over the last $20 \mathrm{yr}$. The coherent response in A. minutissimum and its temporal covariance with changes in elemental fluxes associated with dust suggest that this taxon may be sensitive to changes in the magnitude of dust deposition and its chemical composition. There was also an apparent increase in Encyonema minutum (Hilse) D. G. Mann that appears to parallel the increasing trend in A. minutissimum; however, this similar response is only evident in Senator Beck (Fig. 10b).

\section{Discussion}

\subsection{Changes in dust fluxes}

Our previous work showed that mass accumulation rates in the SJM increased substantially over the past $200 \mathrm{yr}$ in response to an apparent increase in dust deposition (Neff et al., 2008). However, we were unable to provide quantitative estimates of how much of this increase in mass accumulation could be attributed to increases in dust deposition. Here, we have demonstrated that dust is the major contributor to the in-
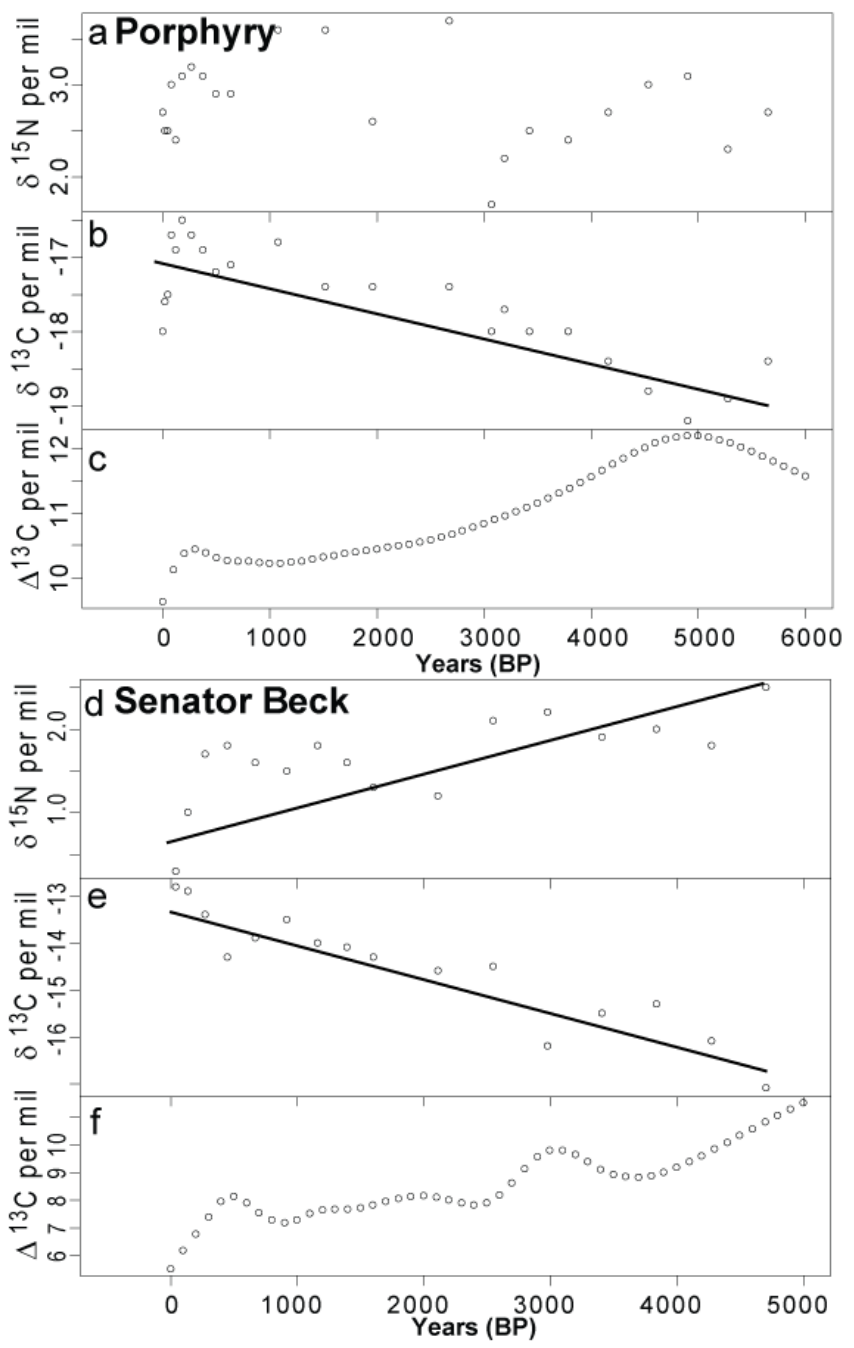

Fig. 9. Changes in the stable isotopic composition of organic carbon and nitrogen in lake sediments over time. Top panels $(\mathbf{a}-\mathbf{c})$ show changes in isotopic composition for Porphyry Lake sediments and bottom panels (d-f) show changes in isotopic composition of Senator Beck Lake sediments. Nitrogen isotopic ratios $\left(\delta^{15} \mathrm{~N}\right)$ of the organic fraction is reported in panels (a) and (d). Carbon isotopic ratios $\left(\delta^{13} \mathrm{C}\right)$ are reported in panels $(\mathbf{b})$ and (e). The isotopic discrimination $\left(\Delta^{13} \mathrm{C}\right.$ ) of organic $\mathrm{C}$ against atmospheric $\mathrm{CO}_{2}$ (Francey et al., 1999) is reported in panels (c) and (f). All isotopic data are reported as per mil.

organic fraction of lake sediments in the SJM. In fact, when we consider all of our isotopic tracers and their concentrations in our mixing model, we see that more than $95 \%$ of the inorganic flux to these sediments is derived from material geochemically similar to modern dust and less than $5 \%$ of the inorganic flux appears to be derived from bedrock in the watershed.

These estimates of the dust fraction in sediments greatly exceed estimates of dust contributions to soils in the SJM that are on the order of 10 to $40 \%$ (Lawrence et al., 2011). 


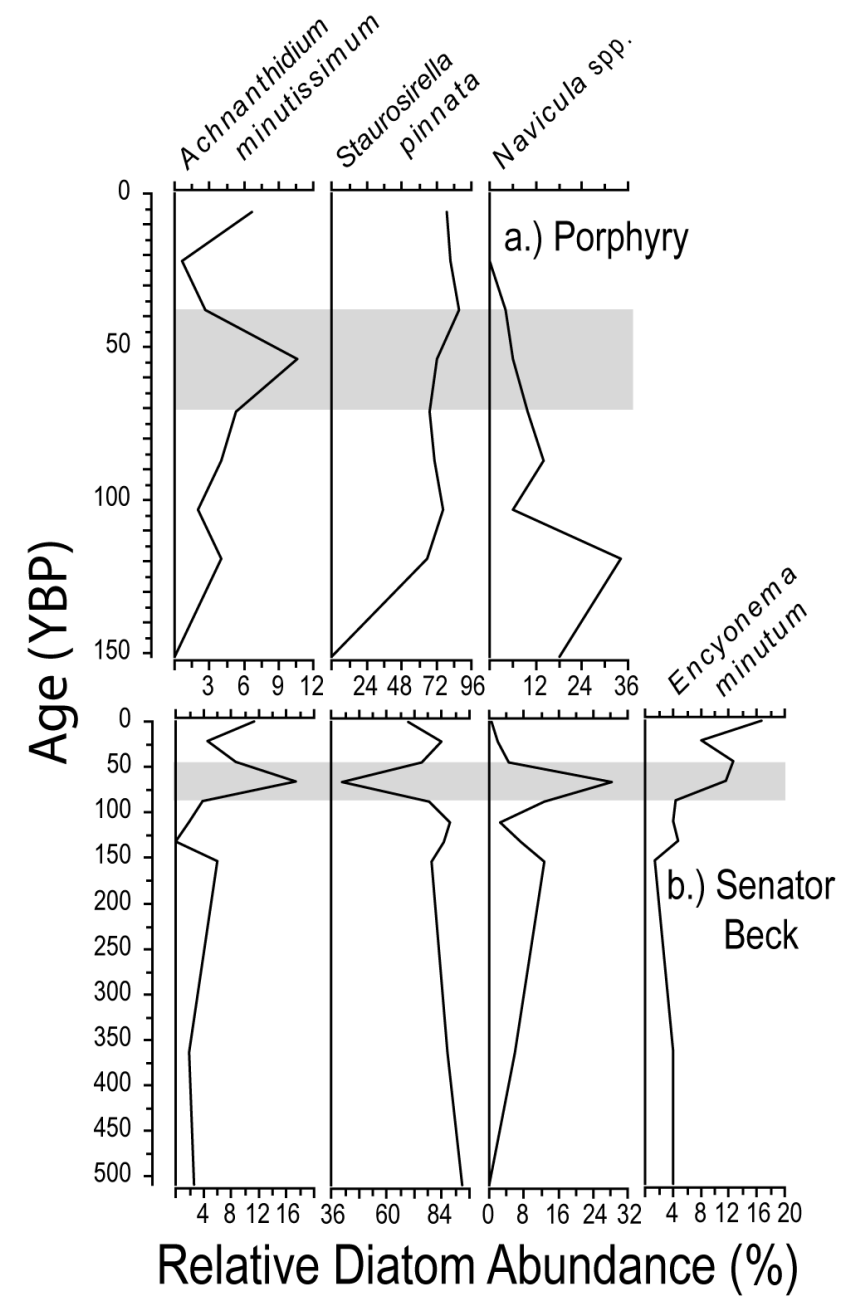

Fig. 10. Contemporary changes in the relative abundance of prominent diatom taxa in both Porphyry (A; top) and Senator Beck (B; bottom) lake sediments. Diatoms are presented in relative abundance for the most prevalent diatom taxa, except Navicula spp. which represents the grouping of several different Navicula species. Intervals highlighted in grey represent periods of maximum dust accumulation for each lake.

The disparity between these estimates suggests that these lakes are integrating a greater temporal span or a greater spatial extent of dust deposition than the soils. The estimated dust fraction in sediments is approximately 3 to 4 times that of soils, which can be explained in part by the limited snow-free season in these alpine watersheds spanning approximately 4 months from June to September (Painter et al., 2007). Although much of the dust contributing to soils in these alpine watersheds is thought to be deposited during winter months (Lawrence et al., 2010), lakes are probably integrating dust deposition directly during summer months and indirectly through run-off during winter months. In fact, it has been shown that wet surfaces are 1.5 to 4 times more efficient at collecting atmospheric deposition of $\mathrm{Ca}, \mathrm{K}, \mathrm{Na}$, and $\mathrm{Cl}$ than dry surfaces (Lewis Jr., 1983), thus it is not surprising that the lakes investigated in this study would be more effective dust collectors than the surrounding dry substrates in their watersheds. Sedimentation rates are also highly variable within individual lakes, with higher sedimentation rates often observed at greater depths. This phenomenon, known as "sediment focusing" (Davis, 1982), may also apply to the watershed scale where material deposited within the catchment is transported to lakes through avalanching or run-off. Such sediment focusing would lead to greater concentrations of dust within our lakes, especially at depth where our sediment cores were collected. Thus lakes are probably integrating more of an atmospheric dust signal over a larger area during winter months and are probably more effective at capturing dust during summer months. Lastly, the relatively high proportion of dust observed in these lakes suggests that alpine lakes in crystalline catchments with limited soil development can be excellent recorders of dust deposition and thus very sensitive to changes in the magnitude and chemical composition of dust deposition.

There are only slight changes in the isotopic geochemistry of rare earth elements with depth indicating that atmospheric dust fluxes have always been an important input to these alpine watersheds (Supplement Fig. S2). For instance, there was only a slight enrichment of ${ }^{87} \mathrm{Sr} /{ }^{86} \mathrm{Sr}$ values in surface sediments (0.71814) compared with values at $6 \mathrm{~cm}$ sediment depth (0.71649) or values at $23 \mathrm{~cm}$ sediment depth (0.71699), none of which are significantly different from modern dust values $(0.71632)(\mathrm{t}$-test; $\mathrm{p}$-value $=0.06)$. However, ${ }^{87} \mathrm{Sr} /{ }^{86} \mathrm{Sr}$ sediment values were significantly different from bedrock $(0.70797)$ (t-test; $\mathrm{p}$-value $=0.00013)$. Although it is possible that the slight enrichment of ${ }^{87} \mathrm{Sr} /{ }^{86} \mathrm{Sr}$ observed in surface sediments is the result of increased weathering (Blum and Erel, 1995), the concentrations of Sr, Nd, and Sm in the sediments do not peak in surface sediments, but rather at $6 \mathrm{~cm}$ depth, which coincides with peak dust loading at approximately $100 \mathrm{yr}$ before present (Neff et al., 2008). If, in fact, isotopic excursions were due to changes in weathering rates we would expect for the concentration of these elements to increase with increasing temperatures over the last century as has been observed in the surface chemistry of other lakes in Southern Colorado (Mast et al., 2010). Furthermore, the inclusion of $\mathrm{Sr}, \mathrm{Nd}$, and $\mathrm{Sm}$ and their respective isotopes in our mixing model lends greater support for a dominant dust fraction because $\mathrm{Nd}$ and $\mathrm{Sm}$ isotopes are less sensitive to incongruent weathering than $\mathrm{Sr}$ (Lawrence et al., 2011). Therefore, assuming that the isotopic signature of regional dust sources in the Southwestern US has not changed appreciably over the last $5000 \mathrm{yr}$, we must conclude that dust deposition has always contributed to the mass flux in these alpine watersheds but that this dust flux has increased in modern times. Lastly, an increase in contemporary dust, with its associated base cations and nutrients, has potential impacts on the biogeochemistry of these alpine watersheds. 
Although differences in the chemical composition of underlying bedrock are obviously important in mediating the biogeochemical response of watersheds to changes in atmospheric deposition, in order to estimate changes in elemental fluxes we must also consider the differences in morphometric properties of these watersheds. The two lakes investigated in this study have very different morphometric properties with respect to their watersheds and these differences affect the total elemental loading to these two watersheds (Fig. 1 and Table 1). Porphyry has a much larger surface area $\left(6920 \mathrm{~m}^{2}\right)$ and also has a much larger watershed area $\left(165910 \mathrm{~m}^{2}\right)$ and therefore integrates a larger atmospheric area than Senator Beck $\left(110 \mathrm{~m}^{2}\right)$, which has a much smaller watershed area $\left(1420 \mathrm{~m}^{2}\right)$. Porphyry also has a watershed area to lake area ratio $(W: L=24: 1)$ that is nearly twice as big as that of Senator Beck $(W: L=13: 1)$, suggesting that Porphyry may be more sensitive to changes in the rate and composition of atmospheric deposition.

Both lakes experienced background sediment accumulation rates of approximately $100 \mathrm{~g} \mathrm{~m}^{-2} \mathrm{yr}^{-1}$, but mass accumulation rates in Porphyry increased by a factor 5 $\left(\sim 500 \mathrm{~g} \mathrm{~m}^{-2} \mathrm{yr}^{-1}\right)$ compared to mass accumulation rates in Senator Beck that increased by only a factor 4 $\left(\sim 400 \mathrm{~g} \mathrm{~m}^{-2} \mathrm{yr}^{-1}\right)$. This greater increase in sediment accumulation rate in Porphyry is consistent with greater atmospheric loading given the larger $W: L$ of Porphyry. However, sediment accumulation rates may vary spatially and temporally even within a single lake and therefore changes in accumulation rates should be interpreted with caution. In fact, the heterogeneous rate of sedimentation within lakes is a well recognized problem (Davis, 1982). Furthermore, as deep lake basins fill, their lake bottom area becomes reduced and thus even if the mass flux to the sediments remained constant there would be an apparent increase in mass accumulation rate. However, the lakes investigated in this study are fairly small and not very deep; thus, we do not suspect that sediment focusing has lead to changes in the mass accumulation rates observed in these lakes. Although there are many factors that may cause changes in sediment accumulation rate, such as physical mixing and changes in water level, the fact that we see a similar change in sediment accumulation rates in these two lakes and that these rates scale to watershed size, suggests that these alpine watersheds are extremely sensitive to changes in atmospheric deposition, similar to lakes located in other locations subjected to frequent dust deposition (Morales-Baquero et al., 2006).

\subsection{Geochemical composition of dust}

Broad patterns of elemental enrichment by dust are observed relative to bedrock in both watersheds; however, there are some key distinctions between the watersheds. Several of the elements that were enriched in dust relative to local bedrock (Fig. 5) were also present in higher concentrations in the contemporary sediments (Fig. 6). Elements such as $\mathrm{Mg}, \mathrm{Cu}$, and
Table 4. Watershed mass balance for nitrogen and phosphorus loading to the two alpine watersheds investigated. Values reported with standard deviations $( \pm)$ when available. Flux estimates to lakes are normalized to total watershed area (see Table 1), such that mass flux values are multiplied by [(watershed area + lake surface area)/(lake surface area)].

\begin{tabular}{|c|c|c|}
\hline \multirow{2}{*}{$\begin{array}{l}\text { Watershed Parameters } \\
\text { Mass Fluxes }\end{array}$} & \multicolumn{2}{|c|}{ Alpine Watersheds } \\
\hline & Porphyry & Senator Beck \\
\hline Dust Flux $\left(\mathrm{g} \mathrm{m}^{-2} \mathrm{yr}^{-1}\right)$ & $\sim 10$ & $\sim 10$ \\
\hline Bedrock Weathering $\left(\mathrm{g} \mathrm{m}^{-2} \mathrm{yr}^{-1}\right)$ & $\sim 3$ & $\sim 3$ \\
\hline \multicolumn{3}{|l|}{ Chemical Properties } \\
\hline $\mathrm{P}$ concentration in Dust $\left(\mu \mathrm{gg}^{-1}\right)$ & $902 \pm 138$ & $902 \pm 138$ \\
\hline $\mathrm{P}$ concentration in Bedrock $\left(\mu \mathrm{g} \mathrm{g}^{-1}\right)$ & $288 \pm 29$ & $1111 \pm 163$ \\
\hline $\mathrm{N}$ concentration in Dust $\left(\mu \mathrm{gg}^{-1}\right)$ & $4400 \pm 600$ & $4400 \pm 600$ \\
\hline $\mathrm{N}$ concentration in Bedrock $\left(\mu \mathrm{g} \mathrm{g}^{-1}\right)$ & 0 & 0 \\
\hline \multicolumn{3}{|l|}{ Flux Concentration Estimates } \\
\hline $\mathrm{P}$ flux from Dust $\left(\mathrm{mg} \mathrm{m}^{-2} \mathrm{yr}^{-1}\right)$ & 225 & 125 \\
\hline $\mathrm{P}$ flux from Bedrock $\left(\mathrm{mg} \mathrm{m}^{-2} \mathrm{yr}^{-1}\right)$ & 46 & 47 \\
\hline Total P flux ( $\left.\mathrm{mg} \mathrm{m}^{-2} \mathrm{yr}^{-1}\right)$ & 271 & 172 \\
\hline $\mathrm{N}$ flux wet $\left(\mathrm{mg} \mathrm{m}^{-2} \mathrm{yr}^{-1}\right)$ & 4495 & 2500 \\
\hline $\mathrm{N}$ flux dust $\left(\mathrm{mg} \mathrm{m}^{-2} \mathrm{yr}^{-1}\right)$ & 1098 & 611 \\
\hline Total $\mathrm{N}$ flux $\left(\mathrm{mg} \mathrm{m}^{-2} \mathrm{yr}^{-1}\right)$ & 5593 & 3111 \\
\hline Total N:P flux (molar) & 45.7 & 40.1 \\
\hline
\end{tabular}

$\mathrm{Ca}$ are consistently enriched in dust and contribute heavily to the amount of variance explained in modern sediments. $\mathrm{Mg}$ and $\mathrm{Ca}$ are elements that are often associated with the finer soil fraction that is particularly susceptible to erosion as a result of grazing in the southwestern US (Neff et al., 2005). Thus, some of the elements enriched in dust and contemporary sediments may be derived from regions in the Western US that have been historically overgrazed. Some elements contained in dust, however, show differing patterns of enrichment in the two watersheds (Fig. 5). In particular, Fe, P, $\mathrm{Cd}$, and $\mathrm{Sr}$, are enriched in dust relative to the bedrock in Porphyry, but relatively depleted in dust relative to the bedrock in Senator Beck. The concentration of $\mathrm{P}$ in the bedrock of Senator Beck's watershed is approximately $4 \times$ the concentration of P in the bedrock of Porphyry's watershed (Table 4).

Furthermore, it is not so surprising that $\mathrm{Fe}$ and $\mathrm{P}$ show similar patterns in these two watersheds, as $\mathrm{P}$ and Fe cycles are closely coupled by the adsorption of orthophosphate to iron hydroxides under aerobic conditions typically found in small well-mixed alpine lakes, such as Porphyry and Senator Beck (Jensen et al., 1992). This has been corroborated by leaching experiments demonstrating that most of the $\mathrm{P}$ content in dust from the Southwestern US is associated with the easily remineralized organic fraction (Lawrence et al., 2010). Thus dust deposited in the SJM is consistently enriched in certain cations, such as $\mathrm{Mg}$ and $\mathrm{Ca}$, certain heavy metals, such as $\mathrm{Cr}$, $\mathrm{Ni}$, and $\mathrm{Cu}$, and may be enriched in important nutrients, such as $\mathrm{P}$ and $\mathrm{Fe}$, relative to the underlying bedrock. 


\subsection{Implications for biogeochemistry}

Although both alpine watersheds in this study were subjected to an increase in atmospheric dust deposition, they show very different chemical and biological responses. Both lakes show proportional increases in the accumulation rates of $\mathrm{C}, \mathrm{N}$, and $\mathrm{P}$ in contemporary sediments; however, apparent increases in $\mathrm{C}, \mathrm{N}$, and $\mathrm{P}$ in contemporary sediments would be expected simply due to incomplete diagenesis. There is a certain degree of recycling that occurs at the sediment water interface whereby organically bound $\mathrm{C}, \mathrm{N}$, and $\mathrm{P}$ are remineralized and either complex with other minerals and remain in the sediments, or are re-suspended in the water column and made available for primary productivity, or in the case of $\mathrm{C}$ and $\mathrm{N}$ escape to the atmosphere in gaseous form. Experimental observations of diagenesis suggest that as much as $80 \%$ of particulate organic carbon and as much as $85 \%$ of particulate organic nitrogen can be lost due to diagenesis under oxic conditions (Lehmann et al., 2002), that are typical for shallow alpine lakes (Table 1). However, these experiments also indicate that diagenesis was effectively complete after only 25 days. Moreover, an analysis of varved sediments over time has revealed that as much as $20 \%$ of organic C and as much as $30 \%$ of organic $\mathrm{N}$ can be lost in situ from lake sediments, but that most of this loss occurs in the first $5 \mathrm{yr}$ following deposition (Gälman et al., 2008). Therefore incomplete diagenesis cannot fully explain the increases in organic $\mathrm{C}$ and $\mathrm{N}$ that are observed over 100 to $200 \mathrm{yr}$ in these alpine lakes. It is also known that biogeochemical cycles of $\mathrm{P}$ and $\mathrm{Fe}$ in lakes are tightly coupled and largely regulated by redox potential, such that in oxic lakes with an abundance of Fe present orthophosphate is tightly bound to iron hydroxides in the sediments (Jensen et al., 1992). These alpine lakes have very high concentrations of dissolved oxygen (Table 1) and it is very unlikely that they become anoxic for any length of time there is also an abundance of Fe both delivered in dust and from bedrock weathering (Fig. 5). Therefore it is unlikely that there is much internal loading of $\mathrm{P}$ in these systems once $\mathrm{P}$ is bound to $\mathrm{Fe}$ in the sediments. Lastly, other less mobile elements, such as the base cations $\mathrm{Na}, \mathrm{K}$, and $\mathrm{Ca}$, as well as the metals $\mathrm{Mg}, \mathrm{Cr}, \mathrm{Ni}$, and $\mathrm{Cu}$, that are relatively enriched in dust (Fig. 5), show similar accumulation rates to $\mathrm{C}, \mathrm{N}$, and $\mathrm{P}$ in the sediments of these lakes (Fig. 9 and Neff et al., 2008). Thus the observed increases in $\mathrm{C}, \mathrm{N}$, and $\mathrm{P}$ accumulation rates are probably in response to increased dust loading, either directly through dust-derived organic matter or indirectly through the stimulation of productivity by dustderived nutrients.

The observed increase in organic $\mathrm{C}$ accumulation could be due to increases in allochthonous inputs either from the watershed or from the atmosphere or else an increase in autochthonous inputs from increased primary productivity. The simultaneous increase in $\mathrm{C}$ accumulation and decrease in $\mathrm{C}: \mathrm{N}$ indicates that the observed increase in $\mathrm{C}$ accumulation is not the result of increased carbon from terrestrial plants or macrophytes (Fig. 7c and d), which tend to have greater structural carbon and thus elevated $\mathrm{C}: \mathrm{N}$ ratios (Cross et al., 2000). It is also unlikely that the $\mathrm{C}: \mathrm{N}$ ratio of dust has changed appreciably over time as the source regions for this dust are primarily arid landscapes of the southwestern US with very little agricultural amendments of $\mathrm{N}$ (Reynolds et al., 2001). Therefore the most likely explanation for the observed increase in organic $\mathrm{C}$ accumulation in the past 100 to $200 \mathrm{yr}$ is an increasing autochthonous source due to an increase in primary productivity in response to recent changes in dust loading. In fact, pelagic algae tend to have greatly reduced C:N ratios (Meyers and Teranes, 2001), consistent with an increase in pelagic primary productivity in these systems. Furthermore, this is corroborated by a factor 5 increase in diatom abundance (Supplement Fig. S3) in the modern sediments $\left(\bar{\chi}=887\right.$ diatoms $\left.\mu \mathrm{g}^{-1}\right)$ compared to background sediments $\left(\bar{\chi}=186\right.$ diatoms $\left.\mu \mathrm{g}^{-1}\right)$.

There is also independent evidence of increased dust loading in that the relative concentrations of $\mathrm{C}, \mathrm{N}$, and $\mathrm{P}$ in the sediments of Porphyry were 2 to 3 times the relative concentrations of C, N, and P in the sediments of Senator Beck. This can be explained by the much larger areal extent of the Porphyry watershed that receives greater dust loading from the atmosphere (Fig. 1). The percent of organic $\mathrm{C}$ present in the sediments of both Porphyry and Senator Beck was highly correlated with the percent organic N (Fig. 8 and Table 3), indicating that carbon and nitrogen cycling in these systems are tightly coupled. The percent organic $\mathrm{C}$ in both of these lakes was also correlated with percent P (Fig. 8), although not as strongly (Table 3 ). Although we only measured the total $\mathrm{P}$ fraction in the sediments, these systems have very low concentration of $\mathrm{PO}_{4}^{-3}$ (Table 1) and thus most of the available $\mathrm{P}$ is probably assimilated and deposited as organic $\mathrm{P}$ in the sediments. Furthermore, both of the lakes show a substantial increase in the accumulation of $\mathrm{P}$ in modern sediments, even Porphyry which has very little P in the surrounding bedrock. These results are consistent with evidence from Colorado lakes that receive very little atmospheric Ndeposition, in which mesocosm experiments showed a much stronger response in primary productivity to $\mathrm{N}$ amendments than P amendments (Elser et al., 2009). In fact, our results suggest that the relative N:P availability in some of these lakes in southern Colorado may actually be reduced by $\mathrm{P}$ delivered with dust. The strong correlations between organic carbon content and nitrogen availability and to a lesser extent phosphorus availability in these alpine watersheds indicate that both these nutrients may be important in regulating primary productivity. This is consistent with emerging evidence that primary productivity in lakes on a global scale is co-limited by the availability of $\mathrm{N}$ and P (Lewis Jr. and Wurtsbaugh, 2008).

The observed enrichment of $\delta^{13} \mathrm{C}$ in the organic fraction of modern sediments from both lakes can be explained by three likely mechanisms: (1) changes in the source of organic C contributing to the sediments (Meyers and Teranes, 2001), 
(2) changes in primary productivity (Brenner et al., 1999), or (3) alteration due to diagenesis (Lehmann et al., 2002). Here we will consider each of these mechanisms and their possible interactions to explain the similar patterns of $\delta^{13} \mathrm{C}$ observed in our two lakes over time.

Pelagic algae tend to have more depleted values of $\delta^{13} \mathrm{C} \sim-30 \%$ o, similar to $\mathrm{C} 3$ vegetation, whereas benthic algae tend to have values of $\delta^{13} \mathrm{C} \sim-15 \%$, more similar to $\mathrm{C} 4$ vegetation (France, 1995). Because there is virtually no vegetation and very little soil development in either of these watersheds (Fig. 1), we can eliminate the possibility of terrestrial vegetation contributing to this trend towards greater enrichment. This trend could also result from a shift from pelagic algae towards more benthic algae, possibly in response to changes in lake level (Ballantyne et al., 2011). However, there was no evidence of benthic algae or macrophytes at the sediment-water interface in either of these lakes when cores were extracted and a shift towards more benthic algae or macrophytes would be accompanied by an increase in the C:N ratio of the sediment organic matter (Cross et al., 2000), which is also not observed in either lake. Thus it does not appear that the observed trends in $\delta^{13} \mathrm{C}$ are due to changes in the source of organic $\mathrm{C}$ contributing to the sediments.

The other possible explanation for the observed enrichment of $\delta^{13} \mathrm{C}$ is a change in primary productivity. In fact, changes in $\delta^{13} \mathrm{C}$ of the organic fraction of sediments are often interpreted as changes in primary productivity (O'Reilly et al., 2003; Brenner et al., 1999). As rates of primary productivity increase the pool of available dissolved inorganic carbon is reduced and the degree to which algae discriminate against the heavier ${ }^{13} \mathrm{C}$ is diminished (Brenner et al., 1999). This predicted decrease in isotopic discrimination corresponding with an increase in primary productivity is what we see when the data are corrected for changes in $\delta^{13} \mathrm{C}$ of atmospheric $\mathrm{CO}_{2}$ and expressed as $\Delta^{13} \mathrm{C}$ (Fig. 9). This interpretation is also corroborated by an increase in diatom concentrations in contemporary sediments (Supplement Fig. S3).

Diagenesis may also be invoked as a mechanism affecting the isotopic composition of organic $\mathrm{C}$ in our lake sediments. Laboratory experiments suggest that diagenesis under both anoxic and oxic conditions leads to an isotopic depletion of the particulate organic carbon pool (Lehmann et al., 2002). These results have been corroborated by in situ observations showing a relatively constant isotopic depletion of approximately $1 \%$ o between sedimentary organic carbon and particulate organic carbon in the water column (Lehmann et al., 2002). However, our sediments show no clear evidence of isotopic depletion at the surface and thus diagenesis could contribute to a constant $\sim 1 \%$ offset in the sediment organic fraction, but this cannot explain the long term secular trend observed in these lakes over the last 3000 to $5000 \mathrm{yr}$.

Therefore the observed trends in $\delta^{13} \mathrm{C}$ of organic sediments are primarily the result of increased primary productivity in response to dust loading that has accelerated over the last $200 \mathrm{yr}$. It is also likely that the original signal of $\delta^{13} \mathrm{C}$ of the organic fraction has been altered by diagenesis, but there is no reason to believe that this alteration due to diagenesis has changed over time and thus is probably a constant isotopic offset.

\subsection{Nutrient mass balance for alpine watersheds}

Knowledge of modern dust fluxes, weathering fluxes, and their respective chemical properties, as well as watershed dimensions allows us to calculate independent budgets of phosphorus and nitrogen for these two watersheds (Table 4). Mass fluxes of dust in the SJM measured from the snowpack are approximately $10 \mathrm{~g} \mathrm{~m}^{-2} \mathrm{yr}^{-1}$ (Lawrence et al., 2010), which is roughly 3 times estimates of bedrock weathering $\left(3 \mathrm{~g} \mathrm{~m}^{-2} \mathrm{yr}^{-1}\right)$ for the SJM (Caine, 1979). Although there is considerable inter-annual variability in our estimates of dust loading, this variability is primarily due to ENSO variability (Reheis, 2006) and thus our estimates of dust loading spanning $5 \mathrm{yr}$ are probably representative of the mean annual dust loading. Moreover our estimates of total annual dust loading are probably fairly conservative as we only measured discrete events in the snowpack during winter months (Lawrence et al., 2010).

Phosphorus concentrations in dust $\left(902 \mu \mathrm{gg}^{-1}\right)$ are relatively low compared to $\mathrm{P}$ concentrations in the bedrock of the Senator Beck Watershed $\left(1111 \mu \mathrm{g} \mathrm{g}^{-1}\right)$ and relatively high compared to $\mathrm{P}$ concentrations in the bedrock of Porphyry $\left(288 \mu \mathrm{g} \mathrm{g}^{-1}\right)$. Even though the concentration of $\mathrm{P}$ is much higher in the bedrock of Senator Beck, the smaller watershed to surface area ratio yields a mass flux of $\mathrm{P}$ from bedrock weathering $\left(47 \mathrm{mg} \mathrm{m}^{-2} \mathrm{yr}^{-1}\right)$ that is almost identical to the mass flux of $\mathrm{P}$ from bedrock weathering in Porphyry $\left(46 \mathrm{mg} \mathrm{m}^{-2} \mathrm{yr}^{-1}\right)$. Generally, P fluxes derived from atmospheric dust deposition are much higher than fluxes from bedrock weathering because the dust fluxes are greater (Table 1). However, assuming that all atmospherically-derived $P$ is ultimately transported to lake sediments, atmosphericallyderived $\mathrm{P}$ fluxes in Senator Beck $\left(125 \mathrm{mg} \mathrm{m}^{-2} \mathrm{yr}^{-1}\right)$ are approximately half the atmospherically-derived $\mathrm{P}$ fluxes in Porphyry $\left(225 \mathrm{mg} \mathrm{m}^{-2} \mathrm{yr}^{-1}\right)$. Therefore the total $\mathrm{P}$ loading from weathering and atmospheric deposition are considerably higher in Porphyry $\left(271 \mathrm{mg} \mathrm{m}^{-2} \mathrm{yr}^{-1}\right)$ than in Senator Beck $\left(172 \mathrm{mg} \mathrm{m}^{-2} \mathrm{yr}^{-1}\right)$.

The greater mass balance P flux estimates in Porphyry than Senator Beck based on modern direct measurements are consistent with greater inferred $P$ fluxes in the sediments of Porphyry (Fig. 7); however, sediment P fluxes inferred from both lakes are approximately double our $\mathrm{P}$ flux estimates based on mass balance, possibly due to the greater fraction of autochthonous organic material in more contemporary sediments. Similar increases in $\mathrm{P}$ content of contemporary sediments have been observed for the nearby Uinta Mountains of Utah (Reynolds et al., 2010), perhaps indicating a more coherent regional change in the chemical composition 
of atmospheric deposition. However, increases in $\mathrm{P}$ content of sediments in the Utah lakes were attributed to the recent increase $(\sim 1960)$ in nearby $\mathrm{P}$ mining (Reynolds et al., 2010), whereas $P$ accumulation rates in the SJM began to increase much earlier $(\sim 1800)$ probably due an increase in the prevalence and intensity of grazing (Neff et al., 2008). Lastly, background $P$ accumulation rates were approximately $100 \mathrm{mg} \mathrm{m}^{-2} \mathrm{yr}^{-1}$, which is approximately double the P fluxes derived from bedrock weathering alone, suggesting that atmospherically-derived $\mathrm{P}$ loading has always been an important source of $\mathrm{P}$ to these alpine watersheds but that contemporary atmospherically-derived $\mathrm{P}$ loading has increased.

Similarly, we can estimate the mass balance of $\mathrm{N}$ in our two watersheds. Assuming negligible amounts of $\mathrm{N}$ in the underlying bedrock, almost all of the $\mathrm{N}$ loading to these watersheds is derived from the atmosphere. Based on our estimates of annual dust flux and the concentration of $\mathrm{N}$ in dust $\left(4400 \mu \mathrm{g} \mathrm{g}^{-1}\right)$ we can estimate total dry $\mathrm{N}$ deposition to be approximately $44 \mathrm{mg} \mathrm{m}^{-2} \mathrm{yr}^{-1}$. The annual mean deposition of wet $\mathrm{N}$ at nearby Molas Pass $\left(37.7^{\circ} \mathrm{N},-107.7^{\circ} \mathrm{W}\right)$ from 1994-2009 was approximately $180 \mathrm{mg} \mathrm{m}^{-2} \mathrm{yr}^{-1}$. Thus if we correct for the different watershed to surface area ratios, we see that total $\mathrm{N}$ fluxes to these two lakes are quite different (Table 4). The total $\mathrm{N}$ flux to Porphyry (5593 $\mathrm{mg} \mathrm{m}^{-2} \mathrm{yr}^{-1}$ ) is almost double the total $\mathrm{N}$ flux to Senator Beck (3111 $\mathrm{mg} \mathrm{m}^{-2} \mathrm{yr}^{-1}$ ). These flux estimates from atmospheric measurements are largely in agreement with the modern $\mathrm{N}$ accumulation rates in the sediments of Porphyry and Senator Beck (Fig. 7) suggesting that much of the $\mathrm{N}$ flux from the atmosphere to these alpine watersheds is accumulated in the sediments. These results are corroborated by other mass balance studies that have shown atmospheric deposition can account for most of the $\mathrm{Ca}$ (Pulido-Villena et al., 2006) and dissolved organic carbon (Mladenov et al., 2009) budgets in alpine watersheds. Our results indicate that sediments may in fact reflect changes in the relative loading of important dust-derived elements, such as $\mathrm{Ca}$ and $\mathrm{P}$ (Neff et al., 2008).

Changes in diatom abundance and assemblage provide independent evidence of biological response to increased dust loading to alpine watersheds of the SJM (Fig. 10). Although we only have absolute diatom abundance data for Porphyry, these data indicate that diatom productivity has increased by a factor of 5 (Supplement Fig. S3), which corresponds in magnitude and timing with our inferred increase in dust loading. Shifts in diatom assemblages were observed in both Porphyry and Senator Beck during the interval in which we suspect that dust deposition reached its maximum. In both Porphyry and Senator Beck there was a clear and coherent increase in A. minutissimum between 50 and $75 \mathrm{yr}$ ago. Unfortunately, there are no rigorous transfer functions correlating particular diatom taxa with specific environmental parameters for the SJM. However, low alkalinity lakes from other regions indicate that the $\mathrm{pH}$ and TP optima for A. minutis- simum and $S$. pinnata are quite similar, with $\mathrm{pH}$ optima between 7 and 8 and TP optima between 8 and $14 \mu \mathrm{g} 1^{-1}$ (Dixit et al., 1999; Camburn and Charles, 2000). A regional diatom survey in the SJM also found that $A$. minutissimum was abundant at sites with elevated $\mathrm{pH}$ levels between 7.8 and 8.0 (Sgro et al., 2007). Such elevated pH levels would result from an influx of base cations associated with dust, but the optimal range of TP is hardly indicative of eutrophic conditions, suggesting that an increase in dust-derived $\mathrm{P}$ resulted in only a modest increase in primary productivity. It is also possible that the coherent response of $A$. minutissimum is the result of a common climatic driver leading to changes in lake level at this time. Although broad patterns of drought in the Western US are evident from 1930-1940 and from 19501960 (Cook et al., 2004), it is unclear whether these broad patterns were consistent at the local scale in the SJM and it is very difficult to correlate events in our low-resolution data with higher resolution climate data. Unfortunately, it is very difficult to deconvolve dust and drought signals in these alpine watersheds as periods of prolonged drought tend to result in increased dust emissions. Further research should be conducted on the link between drought and dust emissions to evaluate to what extent climate has controlled background dust emissions and to what extent humans have altered dust emissions.

In summary, differences in the underlying bedrock chemistry and watershed morphometry have mediated how these two watersheds have responded to similar increases in dust loading. Although Senator Beck has surprisingly high concentrations of $\mathrm{P}$ in the underlying bedrock, it has a relatively low watershed to surface area ratio. In contrast, Porphyry has a much lower $\mathrm{P}$ concentration in the underlying bedrock with a higher watershed to surface area ratio. Thus Senator Beck receives a greater fraction of endogenous $\mathrm{P}$ from the watershed but the overall $\mathrm{P}$ loading is greater for Porphyry (Table 4). Similarly the total N loading is much higher for Porphyry than Senator Beck because of its larger watershed to surface area ratio. Ultimately, the N:P molar flux is higher in Porphyry (45.7) than in Senator Beck (40.2). These ratios of molar fluxes are, however, much higher than those observed in the sediments of Porphyry (mean $\mathrm{N}: \mathrm{P}=12.2$ ) and Senator Beck (mean $\mathrm{N}: \mathrm{P}=9.5$ ). This suggests perhaps that $\mathrm{P}$ is more retained in these catchments and that $\mathrm{N}$ may be lost due to denitrification in the watershed, or the sediments, or else lost due to runoff. The lower N:P ratio of Senator Beck sediments indicates that $\mathrm{N}$-limitation should exert greater control on primary productivity in this system. In fact, this is consistent with the gradual depletion of $\delta^{15} \mathrm{~N}$ observed in the sediments of Senator Beck that is most likely due to $\mathrm{N}$ fixation. Although increases in $\mathrm{N}$ deposition due to fossil fuel combustion also may result in depleted $\delta^{15} \mathrm{~N}$ values (Wolfe et al., 2001), $\mathrm{N}$ deposition in the SJM is not particularly high and we would expect regional patterns in $\mathrm{N}$ deposition to be reflected in both sediment records. Furthermore, the onset in progressive depletion in $\delta^{15} \mathrm{~N}$ observed in Senator Beck 
( $\sim 5000 \mathrm{YBP})$ is well before widespread industrial processes began to cause an isotopic depletion of atmospheric $\mathrm{NO}_{3}$, approximately $150 \mathrm{yr}$ ago (Hastings et al., 2009). Based on a survey of Northern Hemisphere lakes (Elser et al., 2009), the onset of N-limitation of primary productivity should occur below an N:P ratio of atmospheric deposition of approximately 75. This threshold is considerably higher than the ratios estimated in our watersheds, which are classified as lakes of "low N deposition" according to Elser et al. (2009). Changes in lake chemistry in response to atmospheric deposition have been shown to vary based on bedrock chemistry in other alpine watersheds of Colorado (Mast et al., 2010). Despite the widespread reduction in sulfur emissions (Likens et al., 1996), $\mathrm{SO}_{4}$ concentrations in some alpine lakes of Colorado have actually increased due to increased weathering of $\mathrm{FeS}_{2}$ in their catchments (Mast et al., 2010). These studies highlight the importance of underlying geology in mediating the biogeochemical response of alpine ecosystems to global change. Regardless, we can conclude that alpine lakes are sensitive to changes in the magnitude and chemical composition of atmospheric deposition and their degree of sensitivity may be determined in part by their physical and chemical properties.

\section{Conclusions}

Lakes are bellwethers of global change because they integrate physical, chemical, and biological processes occurring in their watersheds (Williamson et al., 2009). Alpine watersheds are also sensitive indicators of changes in atmospheric deposition because there is often very little vegetation or soil to dampen the impacts of changes in the magnitude or chemical composition of atmospheric deposition. Here we have demonstrated that alpine lakes may present valuable geochemical archives for reconstructing changes in atmospheric deposition. Lakes in the SJM of southern Colorado indicate that dust deposition has increased between 300 and $500 \%$ (Neff et al., 2008). Not only does this dust have an important direct impact on the radiative budget of the atmosphere (Winckler et al., 2008) and the snowpack (Painter et al., 2007), it is also an important vector for transporting nutrients. Dust, as a nutrient vector, has likely impoverished disturbed arid ecosystems of essential nutrients while enriching adjacent alpine ecosystems with essential nutrients. Here we show that increased dust loading has likely lead to the enrichment of alpine watersheds in important nutrients, such as $\mathrm{N}$ and $\mathrm{P}$, base cations, such as $\mathrm{Ca}$ and $\mathrm{Mg}$, and also certain metals, such as $\mathrm{Cr}, \mathrm{Cu}$, and $\mathrm{Ni}$. Although this increase in dust loading appears to be regionally coherent over the SJM, local properties, such as watershed dimensions and underlying bedrock geology may amplify or dampen the ecosystem response to these atmospherically derived nutrient subsidies.

\section{Supplementary material related to this article is available online at: http://www.biogeosciences.net/8/2689/2011/ bg-8-2689-2011-supplement.pdf.}

Acknowledgements. We would like to thank Cody Flagg, Sarah Castle, and Chris Landry for assistance with fieldwork. We also appreciate the assistance of John Drexler and Paul Bonny in the Department of Geological Sciences, CU Boulder who helped with sample preparation and analysis. Logistical support was also provided by the Mountain Studies Institute of Silverton, Colorado, USA. This work was supported by the US National Science Foundation Awards \#0948823 and \#1027341. Additional support to A. P. B. was also provided through the National Research Council, USA.

Edited by: S. W. A. Naqvi

\section{References}

Appleby, P. G. and Oldfield, F.: The Assessment of Pb-210 Data from Sites with Varying Sediment Accumulation Rates, Hydrobiologia, 103, 29-35, 1983.

Ballantyne, A. P., Baker, P. A., Fritz, S. C., and Poulter, B.: Climatemediated nitrogen and carbon dynamics in a tropical watershed, J. Geophys. Res., 116, G02013, doi:10.1029/2010JG001496, 2011.

Baron, J. S., Rueth, H. M., Wolfe, A. M., Nydick, K. R., Allstott, E. J., Minear, J. T., and Moraska, B.: Ecosystem responses to nitrogen deposition in the Colorado Front Range, Ecosystems, 3, 352-368, 2000.

Blum, J. D. and Erel, Y.: A silicate weathering mechanism linking increases in marine ${ }^{87} \mathrm{Sr} /{ }^{86} \mathrm{Sr}$ with global glaciation, Nature, 373, 415-418, 1995.

Brenner, M., Whitmore, T. J., Curtis, J. H., Hodell, D. A., and Schelske, C. L.: Stable isotope (delta13C and delta15N) signatures of sedimented organic matter as indicators of historic lake trophic state, J. Paleolimnol., 22, 205-221, 1999.

Caine, N.: Rock weathering rates at the soil surface in an alpine environment, Catena, 6, 131-144, 1979.

Camburn, K. E. and Charles, D. F.: Diatoms of low-alkalinity lakes in the northeastern United States, Special Publications 18, edited by: Spamer, E. E., Academy of Natural Sciences of Philadelphia, Philadelphia, PA, USA, 2000.

Catalan, J.: The winter cover of a high-mountain Mediterranean lake (Estany Redó, Pyrenees), Water Resour. Res., 25, 519-527, 1989.

Cook, E. R., Woodhouse, C. A., Eakin, C. M., Meko, D. M., and Stahle, D. W.: Long-Term Aridity Changes in the Western United States, Science, 306, 1015-1018, 2004.

Cross, S. L., Baker, P. A., Seltzer, G. O., Fritz, S. C., and Dunbar, R. B.: A new estimate of the Holocene lowstand level of Lake Titicaca, central Andes, and implications for tropical palaeohydrology, The Holocene, 10, 21-32, 2000.

Davis, M. B.: Sediment focusing in Mirror Lake, New Hampshire, Limnol. Oceanogr., 27, 137-150, 1982.

DeMaster, D. J., McKee, B. A., Nittrouer, C. A., Jiangchu, Q., and Guodong, C.: Rates of sediment accumulation and particle 
reworking based on radiochemical measurements from continental shelf deposits in the East China Sea, Cont. Shelf Res., 4, 143158,1985

Dixit, S. S., Smol, J. P., Charles, D. F., Hughes, R. M., Paulsen, S. G., and Collins, G. B.: Assessing water quality changes in the lakes of the northeastern United States using sediment diatoms, Can. J. Fish. Aquat. Sci., 56, 131-152, 1999.

Duce, R. A. and Tindale, N. W.: Atmospheric transport of iron and its deposition in the ocean, Limnol. Oceanogr., 36, 1715-1726, 1991.

Elser, J. J., Andersen, T., Baron, J. S., Bergstrom, A. K., Jansson, M., Kyle, M., Nydick, K. R., Steger, L., and Hessen, D. O.: Shifts in lake N:P stoichiometry and nutrient limitation driven by atmospheric nitrogen deposition, Science, 326, 835-837, 2009.

Farmer, G. L., Glazner, A. F., and Manley, C. R.: Did lithospheric delamination trigger late Cenozoic potassic volcanism in the southern Sierra Nevada, California?, GSA Bulletin, 114, 754768, 2002

Farquhar, G. D., Ehleringer, J. R., and Hubick, K. T.: Carbon isotope discrimination and photosynthesis, Annual Reviews in Plant Physiology, 40, 503-537, 1989.

Fenn, M. E., Baron, J. S., Allen, E. B., Rueth, H. M., Nydick, K. R., Geiser, L., Bowman, W. D., Sickman, J. O., Meixner, T., Johnson, D. W., and Neitlich, P.: Ecological Effects of Nitrogen Deposition in the Western United States, BioScience, 53, 404420, 2003

France, R.: Differentiation between littoral and pelagic food webs in lakes using stable carbon isotopes, Limnol. Oceanogr., 40, 1310-1313, 1995.

Francey, R. J., Allison, C. E., Etheridge, D. M., Trudinger, C. M., Enting, I. G., Leuenberger, M. L., Langenfelds, R. L., Michel, E., and Steele, L. P.: A 1000-year high precision record of $\delta^{13} \mathrm{C}$ in atmospheric $\mathrm{CO}_{2}$, Tellus, 51B, 170-193, 1999.

Gälman, V., Rydberg, J., De-Luna, S. S., Bindler, R., and Renberg, I.: Carbon and nitrogen loss rates during aging of lake sediment: Changes over 27 years studied in varved lake sediment, Limnol. Oceanogr., 53, 1076-1082, 2008.

Galloway, J. N., Dentener, F. J., Capone, D. G., Boyer, E. W., Howarth, R. W., Seitzinger, S. P., Asner, G. P., Cleveland, C. C., Green, P. A., Holland, E. A., Karl, D. M., Michaels, A. F., Porter, J. H., Townsend, A. R., and Vorosmarty, C. J.: Nitrogen Cycles: Past, Present, and Future, Biogeochemistry, 70, 153226, doi:10.1007/s10533-004-0370-0, 2004.

Hastings, M. G., Jarvis, J. C., and Steig, E. J.: Anthropogenic Impacts on Nitrogen Isotopes of Ice-Core Nitrate, Science, 324, 1288, doi:10.1126/science.1170510, 2009.

Jensen, H. S., Kristensen, P., Jeppesen, E., and Skytthe, A.: Iron: phosphorus ratio in surface sediment as an indicator of phosphate release from aerobic sediments in shallow lakes, Hydrobiologia, 235, 731-743, 1992.

Krammer, K. and Lange-Bertalot, H.: Bacillariophyceae: Bacillariaceae, Epithemiaceae, Surirellaceae, Bacillariaceae, Epithemiaceae, Surirellaceae, edited by: Verlag, G. F., Lubrecht \& Cramer Ltd, Stuttgart, Germany, 1988.

Lambert, F., Delmonte, B., Petit, J. R., Bigler, M., Kaufmann, P. R., Hutterli, M. A., Stocker, T. F., Ruth, U., Steffensen, J. P., and Maggi, V.: Dust-climate couplings over the past 800,000 years from the EPICA Dome C ice core, Nature, 452, 616-619, 2008.

Lawrence, C. R. and Neff, J. C.: The contemporary physical and chemical flux of aeolian dust: A synthesis of direct measurements of dust deposition, Chem. Geol., 267, 46-63, 2009.

Lawrence, C. R., Painter, T. H., Landry, C. C., and Neff, J. C.: Contemporary geochemical composition and flux of aeolian dust to the San Juan Mountains, Colorado, United States, J. Geophys. Res., 115, G03007, doi:10.1029/2009JG001077, 2010.

Lawrence, C. R., Neff, J. C., and Farmer, G. L.: The accretion of aeolian dust in soils of the San Juan Mountains, Colorado, USA, J. Geophys. Res., 116, F02013, doi:10.1029/2010JF001899, 2011.

Lehmann, M. F., Bernasconi, S. M., Barbieri, A., and McKenzie, J. A.: Preservation of organic matter and alteration of its carbon and nitrogen isotope composition during simulated and in situ early sedimentary diagenesis, Geochem. Cosmochim. Ac., 66, 3573-3584, 2002.

Lewis Jr., W. M.: Collection of Airborne Materials by a Water Surface, Limnol. Oceanogr., 28, 1242-1246, 1983.

Lewis Jr., W. M. and Wurtsbaugh, W. A.: Control of lacustrine phytoplankton by nutrients: erosion of the phosphorus paradigm, Int Rev. Hydrobiol., 93, 446-465, 2008.

Likens, G. E., Driscoll, C. T., and Buso, D. C.: Long-Term Effects of Acid Rain: Response and Recovery of a Forest Ecosystem, Science, 272, 244-246, doi:10.1126/science.272.5259.244, 1996.

Mahowald, N., Jickells, T. D., Baker, A. R., Artaxo, P., BenitezNelson, C. R., Bergametti, G., Bond, T. C., Chen, Y., Cohen, D. D., and Herut, B.: Global distribution of atmospheric phosphorus sources, concentrations and deposition rates, and anthropogenic impacts, Global Biogeochem. Cy., 22, GB4026, doi:10.1029/2008GB003240, 2008.

Martin, J. H.: Glacial-interglacial $\mathrm{CO}_{2}$ change: The iron hypothesis, Paleoceanography, 5, 1-13, 1990.

Mast, M. A., Turk, J. T., Clow, D. W., and Campbell, D. H.: Response of lake chemistry to changes in atmospheric deposition and climate in three high-elevation wilderness areas of Colorado, Biogeochemistry, 98, 1-17, doi:10.1007/s10533-0109443-4, 2010.

Meyers, P. A. and Teranes, J. L.: Sediment organic matter, edited by: Smol, W. M. and Last, J. P., in: Tracking Environmental Change Using Lake Sediments, vol. 2: Physical and Geochemical Methods, Kluwer Academic Publishers, Dordrecht, The Netherlands, 239-269 2001.

Mladenov, N., López-Ramos, J., McKnight, D. M., and Reche, I.: Alpine lake optical properties as sentinels of dust deposition and global change, Limnol. Oceanogr., 54, 2386-2400, 2009.

Morales-Baquero, R., Carrillo, P., Reche, I., and Sánchez-Castillo, P.: Nitrogen-phosphorus relationship in high mountain lakes: effects of the size of catchment basins, Can. J. Fish. Aquat. Sci., 56, 1809-1817, 1999.

Morales-Baquero, R., Pulido-Villena, E., and Reche, I.: Atmospheric inputs of phosphorus and nitrogen to the southwest Mediterranean region: Biogeochemical responses of high mountain lakes, Limnol. Oceanogr., 51, 830-837, 2006.

Mulitza, S., Heslop, D., Pittauerova, D., Fischer, H. W., Meyer, I., Stuut, J.-B., Zabel, M., Mollenhauer, G., Collins, J. A., Kuhnert, H., and Schulz, M.: Increase in African dust flux at the onset of commercial agriculture in the Sahel region, Nature, 466, 226228, 2010.

Munson, S. M., Belnap, J., and Okin, G. S.: Responses of wind erosion to climate-induced vegetation changes on the 
Colorado Plateau, Proc. Natl. Acad. Sci. USA, 108, 3854-3859, doi:10.1073/pnas.1014947108, 2011.

Neff, J. C., Reynolds, R. L., Belnap, J., and Lamothe, P.: Multidecadal impacts of grazing on soil physical and biogeochemical properties in southeast Utah, Ecol. Appl., 15, 87-95, 2005.

Neff, J. C., Ballantyne, A. P., Farmer, G. L., Mahowald, N. M., Conroy, J. L., Landry, C. C., Overpeck, J. T., Painter, T. H., Lawrence, C. R., and Reynolds, R. L.: Increasing eolian dust deposition in the western United States linked to human activity, Nat. Geosci., 1, 189-195, 2008.

O'Reilly, C. M., Alin, S. R., Plisnier, P.-D., Cohen, A. S., and Mckee, B. A.: Climate changes decreases aquatic ecosystem productivity of Lake Tanganyika, Africa, Nature, 424, 766-768, 2003.

Okin, G. S., Mahowald, N., Chadwick, O. A., and Artaxo, P.: Impact of desert dust on the biogeochemistry of phosphorus in terrestrial ecosystems, Global Biogeochem. Cy., 18, GB2005, doi:10.1029/2003GB002145, 2004.

Painter, T. H., Barrett, A. P., Landry, C. C., Neff, J. C., Cassidy, M. P., Lawrence, C. R., McBride, K. E., and Farmer, G. L.: Impact of disturbed desert soils on duration of mountain snow cover, Geophys. Res. Lett., 34, L12502, doi:10.1029/2007GL030284, 2007.

Parnell, A. C., Inger, R., Bearhop, S., and Jackson, A. L.: Source partitioning using stable isotopes: coping with too much variation, PLoS ONE, 5, e9672, doi:10.1371\%2Fjournal.pone.0009672, 2010.

Polis, G. A., Anderson, W. B., and Holt, R. D.: Toward an integration of landscape and food web ecology: the dynamics of spatially subsidized food webs, Annu. Rev. Ecol. Syst., 28, 289-316, 1997.

Prospero, J. M. and Lamb, P. J.: African droughts and dust transport to the Caribbean: Climate change implications, Science, 302, 1024, doi:10.1126/science.1089915, 2003.

Psenner, R.: Living in a Dusty World: Airborne Dust as a Key Factor for Alpine Lakes, Water Air Soil Poll., 112, 217-227, 1999.

Pulido-Villena, E., Reche, I., and Morales-Baquero, R.: Significance of atmospheric inputs of calcium over the southwestern Mediterranean region: High mountain lakes as tools for detection, Global Biogeochem. Cy., 20, GB2012, doi:10.1029/2005GB002662, 2006.

$\mathrm{R}$ : A language and environment for statistical computing, R Foundation for Statistical Computing, open access statistical software, ISBN 3-900051-07-0, available at: http://www.R-project.org, 2007.
Reche, I., Ortega-Retuerta, E., Romera, O., Pulido-Villena, E., Morales-Baquero, R., and Casamayor, E. O.: Effect of Saharan dust inputs on bacterial activity and community composition in Mediterranean lakes and reservoirs, Limnol. Oceanogr., 54, 869879, 2009.

Reheis, M. C.: A 16-year record of eolian dust in Southern Nevada and California, USA: Controls on dust generation and accumulation, J. Arid Environ., 67, 487-520, 2006.

Reynolds, R., Belnap, J., Reheis, M., Lamothe, P., and Luiszer, F.: Aeolian dust in Colorado Plateau soils: nutrient inputs and recent change in source, P. Natl. Acad. Sci. USA, 98, 7123-7127, 2001.

Reynolds, R., Mordecai, J., Rosenbaum, J., Ketterer, M., Walsh, M., and Moser, K.: Compositional changes in sediments of subalpine lakes, Uinta Mountains (Utah): evidence for the effects of human activity on atmospheric dust inputs, J. Paleolimnol., 44, 161-175, 2010.

Schindler, D. W., Turner, M. A., Stainton, M. P., and Linsey, G. A.: Natural Sources of Acid Neutralizing Capacity in Low Alkalinity Lakes of the Precambrian Shield, Science, 232, 844-847, doi:10.1126/science.232.4752.844, 1986.

Sgro, G. V., Poole, J. B., and Johansen, J. R.: Diatom species composition and ecology of the Animas River Watershed, Colorado, USA, West. N. Am. Naturalist, 67, 510-519, 2007.

Simonson, R. W.: Airborne dust and its significance to soils, Geoderma, 65, 1-43, 1995.

USDA (United States Department of Agriculture): Geospatial Data Gateway, http://datagateway.nrcs.usda.gov/, 2010.

USGS (United States Geological Survey): Seamless Data Warehouse, http://seamless.usgs.gov/, 2010.

Vitousek, P. M., Aber, J. D., Howarth, R. W., Likens, G. E., Matson, P. A., Schindler, D. W., Schlesinger, W. H., and Tilman, D. G.: Human alteration of the global nitrogen cycle: sources and consequences, Ecol. Appl., 7, 737-750, 1997.

Williams, D. M. and Round, F. E.: Revision of the genus Fragilaria, Diatom Res., 2, 267-288, 1987.

Williamson, C. E., Saros, J. E., and Schindler, D. W.: CLIMATE CHANGE: Sentinels of Change, Science, 323, 887-888, doi:10.1126/science.1169443, 2009.

Winckler, G., Anderson, R. F., Fleisher, M. Q., McGee, D., and Mahowald, N.: Covariant glacial-interglacial dust fluxes in the equatorial Pacific and Antarctica, Science, 320, 93-96, 2008.

Wolfe, A. P., Baron, J. S., and Cornett, R. J.: Anthropogenic nitrogen deposition induces rapid ecological changes in alpine lakes of the Colorado Front Range (USA), J. Paleolimnol., 25, 1-7, 2001. 